\title{
Climate change and crop diversity: farmers' perceptions and adaptation on the Bolivian Altiplano
}

\author{
Gennifer Meldrum ${ }^{1}$ - Dunja Mijatović ${ }^{2}$ - Wilfredo Rojas $^{3}$. \\ Juana Flores $^{3} \cdot$ Milton Pinto $^{3} \cdot$ Grover Mamani $^{4}$. \\ Eleuterio Condori $^{5}$ - David Hilaquita ${ }^{6}$ - Helga Gruberg ${ }^{1,2}$. \\ Stefano Padulosi ${ }^{1}$
}

Received: 6 June 2016/Accepted: 30 December 2016/Published online: 6 January 2017

(C) The Author(s) 2017. This article is published with open access at Springerlink.com

\begin{abstract}
Crop diversity is central to traditional risk management practices on the Andean Altiplano and may find renewed importance in adapting to climate change. This study explored the role of crop diversity in farmers' adaptation actions in eight Aymara communities on the northern Bolivian Altiplano. Using a combination of quantitative and qualitative methods, including multifactor analysis and a community resilience selfassessment, we investigated how farmers' use of diversity in adaptation is related to their perceptions of crop and variety tolerances and other environmental, social, and economic factors. Few crops and varieties were perceived as tolerant to increasingly intense and unpredictable drought, frost, hail, and pest and disease outbreaks. Some local crops and varieties were perceived as vulnerable to emerging conditions (e.g. oca, papalisa, isaño), whereas bitter potatoes and wild relatives of quinoa and cañahua were perceived as highly stress tolerant and provide food in harsh periods. A total 19\% of households surveyed $(N=193)$ had introduced new crops or varieties-often disease resistant or early maturing - as an adaptive action. Introduction of commercial crops was a common adaptation action, reflecting farmers' response to warming temperatures and changing economic opportunities, but greater sensitivity of the introduced crops may cause maladaptation. Despite intensification of cropping systems, households continue to maintain a
\end{abstract}

Electronic supplementary material The online version of this article (doi:10.1007/s10668-016-9906-4) contains supplementary material, which is available to authorized users.

Gennifer Meldrum

g.meldrum@cgiar.org

1 Bioversity International, Via dei Tre Denari 472/a, 00054 Maccarese, Fiumicino, Italy

2 Platform for Agrobiodiversity Research, Via dei Tre Denari 472/a, 00054 Maccarese, Fiumicino, Italy

3 Fundación PROINPA, Calle Américo Vespucio 538, Piso 3, Zona Sopocachi, La Paz, Bolivia

4 CARE, Pasaje Jáuregui 2248, Zona Sopocachi, La Paz, Bolivia

5 Cetha Tupac Katari, Comunidad Corpa, San Andrés de Machaca, La Paz, Bolivia

6 Samaritan's Purse, Calle 17 Monseñor Felipe López 8190, Zona Calacoto, La Paz, Bolivia 
median four potato varieties with different tolerance traits, yet this risk management practice was not perceived as adaptation. Strengthening resilience will require a combination of actions, including maintaining and expanding crop portfolios and restoring soil and ecosystem health, using both traditional and innovative approaches.

Keywords Resilience - Traditional knowledge and practices · Agrobiodiversity · Andes · Stress tolerance $\cdot$ Pests and diseases

\section{Introduction}

The Andean Altiplano is a challenging environment for agriculture due to low rainfall, high evapotranspiration, a short frost-free period, and poor soil fertility (Geerts et al. 2006; Garcia et al. 2007). High interannual variability in precipitation is a constant feature of this high altitude plateau, due to periodic climate oscillations (e.g. El Niño) that bring drought in some years and floods in others (Seiler et al. 2013). Indigenous farmers have traditionally managed this unpredictable and harsh environment by using drought- and frosttolerant crops, keeping many crop varieties, and planting across multiple plots to disperse risk and take advantage of high spatial heterogeneity, among other strategies (Halloy et al. 2005; Perez et al. 2010; McDowell and Hess 2012). The few crops that can tolerate these difficult growing conditions are mainly native roots and grains that have been domesticated by Andean farmers over centuries, including several potato species (e.g. Solanum tuberosum, S. juzepczukii, S. ajanhuiri, and S. curtilobum), quinoa (Chenopodium quinoa), cañahua (Chenopodium pallidicaule), oca (Oxalis tuberosa), papalisa (Ullucus tuberosus), and isaño (Tropaeolum tuberosum) (Garcia et al. 2007; Del Castillo et al. 2008; MachidaHirano 2015).

A multitude of varieties exists within Andean crops as a result of high variation in agroecological conditions, outcrossing with wild relatives, and long-standing cultural practices of seed selection and exchange (Brush et al. 1981; Johns and Keen 1986; Zimmerer 1991; Thiele 1999). Andean farmers distinguish thousands of potato varieties on the basis of morphology, phenology, ecology, and organoleptic attributes (La Barre 1947; Brush et al. 1992; de Haan 2009). Different varieties of quinoa are adapted to a range of growing conditions and display diverse grain colours, shapes, inflorescence sizes, and seed characteristics (Del Castillo et al. 2008; Bazile et al. 2013). Cañahua, oca, papalisa, and isaño also exhibit high intraspecific variation (Malice and Baudoin 2009; Vargas et al. 2011; Velasquez-Milla et al. 2011; Mutegi et al. 2015). Because of this exceptional diversity, the Andean highlands — and notably the Lake Titicaca region-are recognized as a centre of globally important crop genetic resources (Garcia et al. 2007; Velasquez-Milla et al. 2011). However, many local varieties have been abandoned in recent years with the intensification of production and associated breakdown of traditional land management and crop rotation systems (Hellin and Higman 2005; Velasquez-Milla et al. 2011; Gilles et al. 2013; Lennox 2015).

Decline in crop diversity and its use in traditional risk management may have implications for the resilience of Andean farm systems-especially under climate change, which is amplifying existing stresses and making the environment more unpredictable. Rising temperatures, glacial retreat, and shifts in the frequency and intensity of precipitation and frost events have been documented in the Andean highlands over the last 30 years (Bradley 
et al. 2006; Vuille et al. 2008; Perez et al. 2010; Thibeault et al. 2010; Valdivia et al. 2010). Further increase in temperature and variability are projected that will impact water supplies and crop yields (Bradley et al. 2006; Valdivia et al. 2010; Seiler et al. 2013). Some local crops and varieties may be key assets for adaptation because of their stress tolerance (Sanabria and L'Homme 2013; Ruiz et al. 2014); however, others may be vulnerable to the rapidly changing agroecological conditions (Velasquez-Milla et al. 2011). The importance of crop diversity for resilience and adaptation of farm systems to climate change is highlighted by numerous studies, particularly for its critical roles in spreading risk of harvest loss and enabling long-term crop adaptation (Pusadee et al. 2009; Jackson et al. 2010; Zimmerer 2010; Vigouroux et al. 2011; Mijatović et al. 2013; Thomas et al. 2015). In this sense, diversity-based risk management strategies using local crops and varieties, which are central to indigenous farming practices, could find renewed importance in adapting to climate change on the Altiplano.

This study on the northern Altiplano of Bolivia explored the role of crop diversity in farmers' adaptation to climate change, which we define as actions to moderate harm or take advantage of opportunities from actual or anticipated climate conditions (IPCC 2014). We focused on farmers' perceptions because they inform their planting decisions and other actions that determine their resilience-ability to cope with, adapt to, and recover from shocks-into the future (Folke et al. 2010). Several studies have documented Andean farmers' perceptions of climate change and their adaptation actions (Young and Lipton 2006; Valdivia et al. 2010; McDowell and Hess 2012; Boillat and Berkes 2013; Lennox 2015), but few have focused on the responses of specific crop varieties to changing conditions and their current uses in adaptation. Using a combination of qualitative and quantitative methods, we assessed how farmers' use of crop diversity in adaptation is related to their perceptions of crop and variety tolerance, as well as other environmental, social, and economic factors.

\section{Methods}

\subsection{Study sites}

This study focused on eight communities on the northern Bolivian Altiplano: Coromata Media, Cachilaya, Suriquiña, Corqueamaya, Erbenkalla, Rosapata, Pucamaya, and Antaquira (Fig. 1). The focal communities were selected from those that had an established relationship with the NGOs conducting the study. Communities that maintained relatively high crop and variety diversity were targeted to elucidate how these resources were performing and being used in facing climate change. All the communities were Aymara-an indigenous people of the Andean highlands and the predominant ethnic group in the Lake Titicaca region. The communities, located in four municipalities in the department of La Paz, varied in size from 25 to 90 households (Table 1).

The eight communities, situated at altitudes between 3800 and $4300 \mathrm{~m}$, represent a range of conditions on the northern Altiplano of Bolivia (Table 1). Coromata Media, Suriquiña, and Corqueamaya are located in the foothills of the Cordillera Real, which borders the Altiplano to the east (Fig. 1). These communities collect water from the rivers and seasonal streams that flow from the mountains and glacial lagoons. Nearby, the community of Cachilaya is situated on the southeast shore of Lake Titicaca where farmers take advantage of nutrient-rich alluvial soils that are deposited and exposed as the lake 


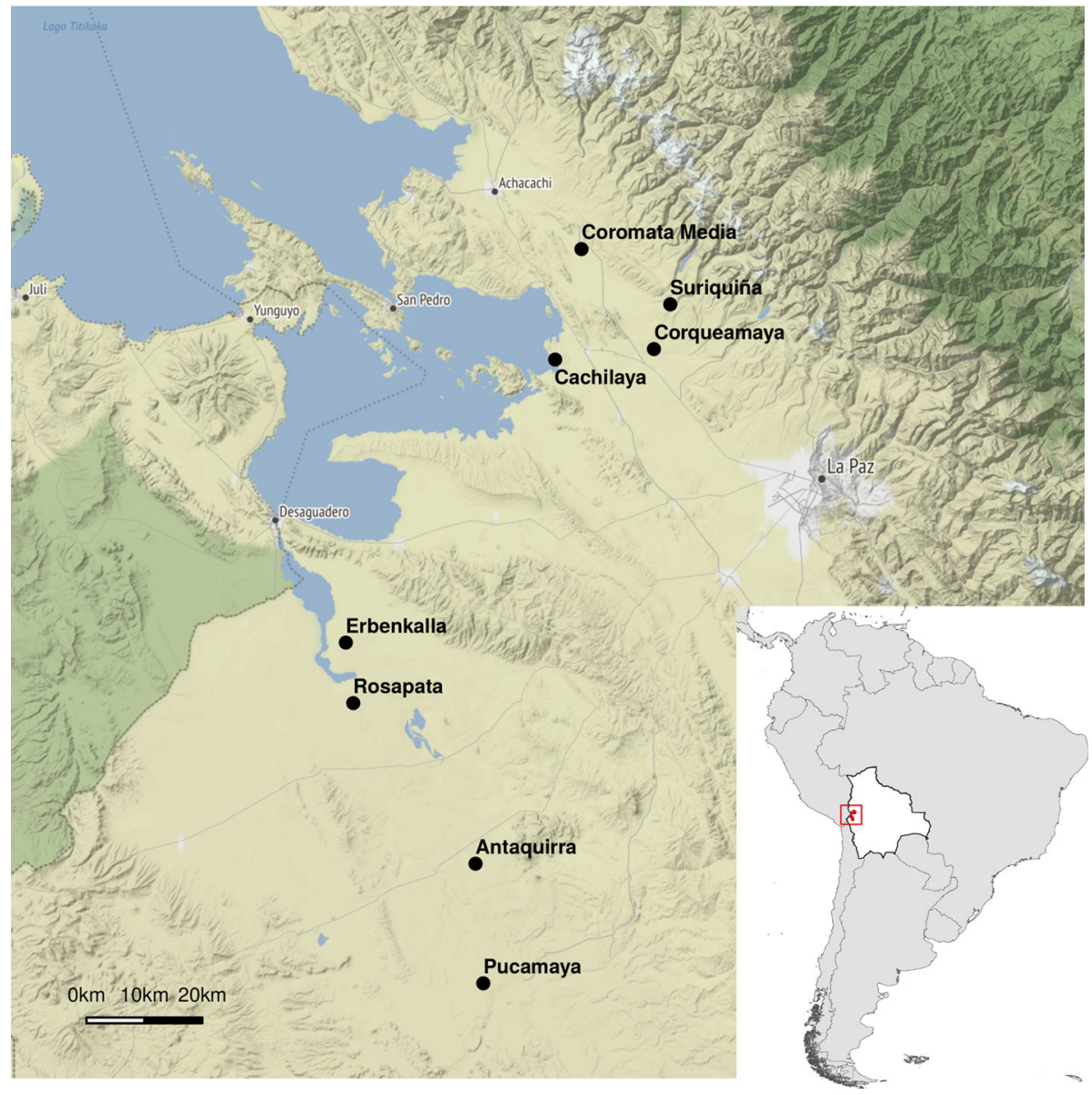

Fig. 1 Map of the eight study communities on the northern Altiplano of Bolivia. Map tiles by Stamen Design, under CC BY 3.0 and data by OpenStreetMap, under ODbL

Table 1 Total number of households, altitude, and administrative locations of the eight study communities in the northern Altiplano of Bolivia

\begin{tabular}{lllll}
\hline Community & Municipality & Province & Altitude (m) & Households (\#) \\
\hline Coromata Media & Huarina & Omasuyos & 3950 & 60 \\
Cachilaya & Batallas & Los Andes & 3870 & 80 \\
Corqueamaya & Batallas & Los Andes & 4015 & 57 \\
Suriquina & Batallas & Los Andes & 4300 & 80 \\
Erbenkalla & San Andres de Machaca & Ingavi & 3830 & 25 \\
Rosapata & San Andres de Machaca & Ingavi & 3850 & 25 \\
Antaquira & Caquiaviri & Pacajes & 3860 & 90 \\
Pucamaya & Caquiaviri & Pacajes & 3890 & 40 \\
\hline
\end{tabular}


level fluctuates from year to year. The other four communities-Erbenkalla, Rosapata, Antaquira, and Pucamaya - are located south of Lake Titicaca in the Desaguadero River basin (Fig. 1). Rainwater and wells are the primary water sources for these communities, as well as for Cachilaya. Annual precipitation on the northern Altiplano of Bolivia is about $600 \mathrm{~mm}$ (Gilles et al. 2013). Drought and frost challenge agricultural production throughout the region and occur more frequently towards the south, further from Lake Titicaca (Gilles et al. 2013).

Farmers in the study communities practice integrated crop and livestock production for a mix of subsistence and commercial purposes. They use many traditional practices inherited from their ancestors and have also adopted some modern practices (e.g. tractors, pesticides, and improved seeds). Potatoes and quinoa are the main crops used both as staples and for commercial purposes. The more southern sites (Antaquira, Pucamaya, Erbenkalla, and Rosapata) have fairly large landholdings ( $>10 \mathrm{Ha}$ ) with most of the area devoted to pasture for camelids, cattle, and sheep. The more northern communities, closer to Lake Titicaca, have smaller landholdings $(<10 \mathrm{Ha})$ and higher crop and variety diversity. Minor tubers (oca, isaño, and papalisa) are grown, as well as a higher number of potato and quinoa varieties. Pigs, cattle, and sheep are the most common livestock. Generally, landholdings across the study communities are getting smaller as plots are divided and handed down to younger generations. At the same time, there is a tendency for men and youth to migrate to find paid jobs and better livelihood opportunities.

\subsection{Household survey}

The household survey was carried out in the eight study communities from December 2011 through January 2012. All the households in each community were invited to participate in the study, which was introduced in a workshop promoted by the local authorities. The survey was conducted with the households that were willing to participate, corresponding to a range between 30 and $100 \%$ of the local population. In total, 193 households were surveyed (Table 2). Interviews were conducted with the head of the household or their spouse if they were not available. Fifty-five per cent of respondents were female, and seventy-eight per cent were over 40 years of age (Table 2). Most surveys were carried out in Spanish, but some were carried out in Aymara when needed. The interview, lasting about $1 \mathrm{~h}$, assessed respondents' perceptions of climate changes in the last 20 years, which crops they perceived to be tolerant and susceptible to the emerging stresses, and their adaptation actions. These aspects were assessed in open questions and the responses matched to a set of common answers. The survey also collected details on the respondents and their farms, including the crop and livestock species they maintain and the number of varieties they cultivate for each crop. It is noted that there may be differences in how individual farmers perceived and counted the number of varieties they maintained. However, the levels of variety diversity captured in the survey broadly agreed with measurements using other methods (e.g. four cell analysis, community biodiversity registers) and direct observations by technicians, so the results were considered representative of the actual levels of diversity maintained.

\subsection{Focus group discussions}

Focus groups were held in December 2014 to share, validate, and explore the findings of the household survey in greater detail. A call for participation was made in each community, leveraging the close relationships the researchers developed with farmers and their 


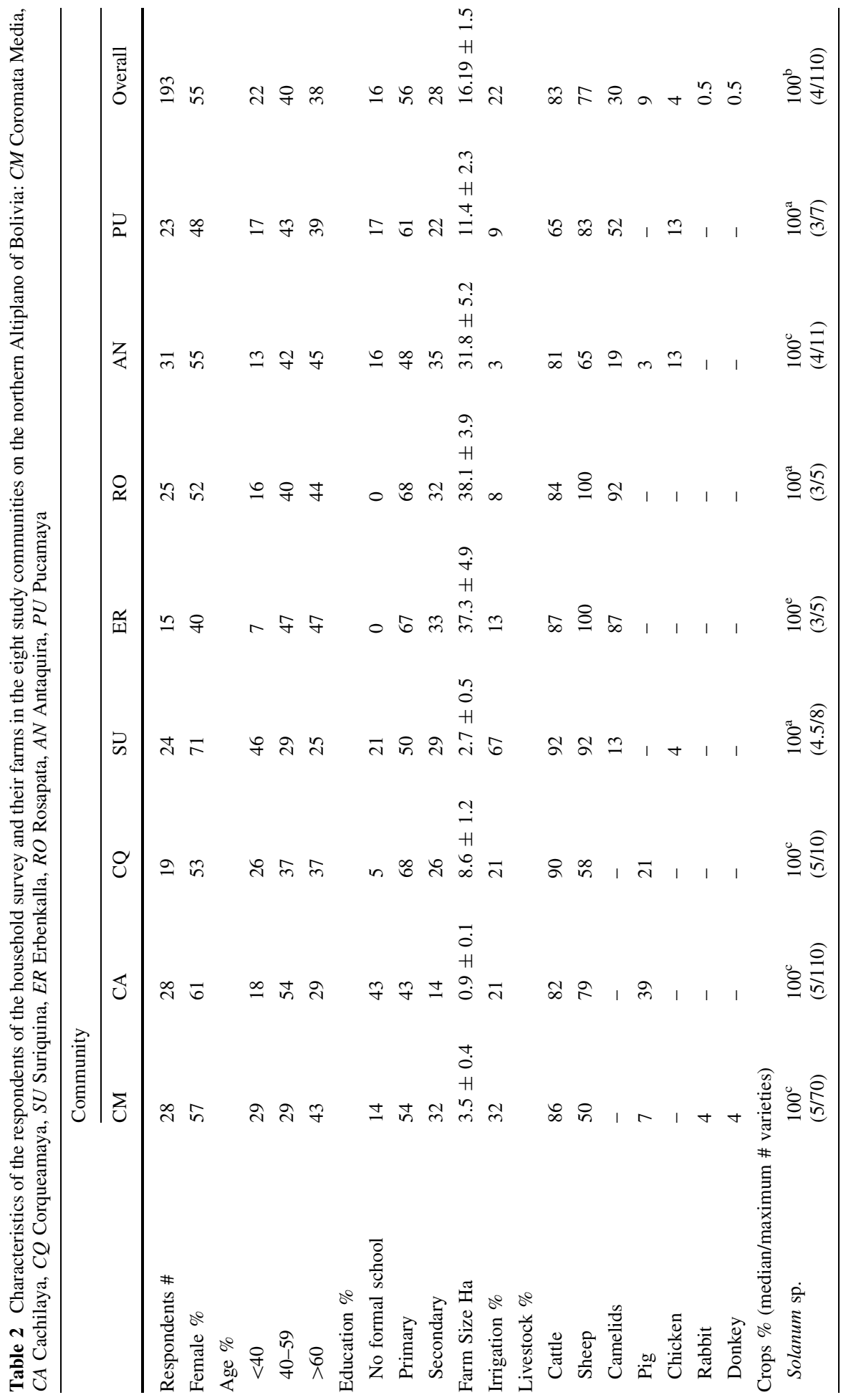




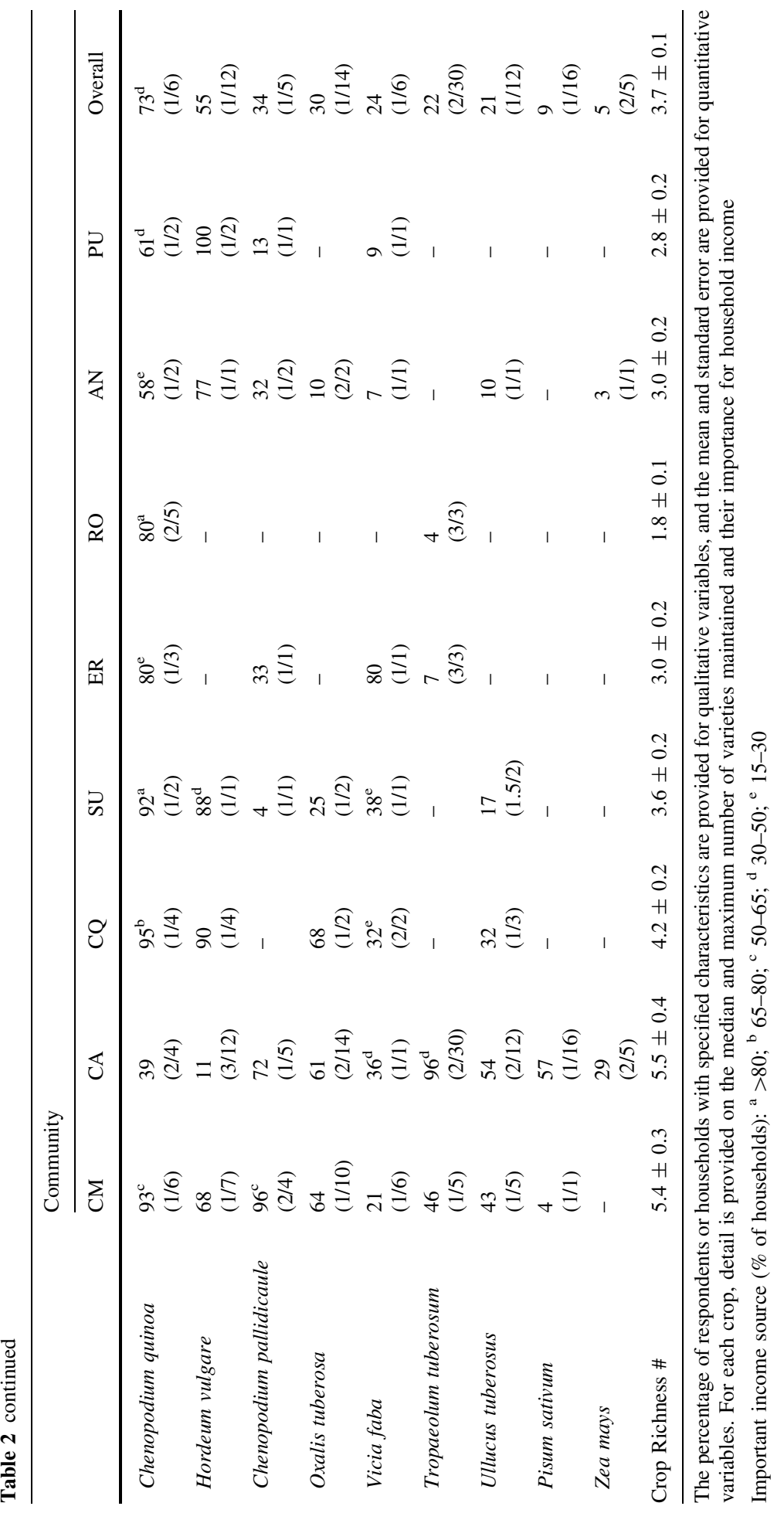


organizations over years of engagement. Between 7 and 17 farmers participated in the focus groups in each community, among which $25-71 \%$ were women (Table 3 ). The age of the participants was not documented, but they were predominantly middle aged to elderly. In each community, the participants were split into three smaller groups with a minimum of three people, including men and women, to address specific sections of the discussion. The facilitators requested responses from both men and women for each question. Discussion continued to reach a consensus answer, but various opinions were documented when they arose.

In each community, one of the three groups focused on changes they had observed over the last 10-20 years, considering the weather, soil, pests and diseases, wildlife, land uses, farming practices, and livelihood strategies, along with reasons for the changes. The second group answered a series of questions to identify crops and varieties that in periods of climate stress: (1) are most likely to fail or have low production, (2) are least likely to fail or have low production, and (3) provide reliable alternative food sources. The stresses to which these crops are tolerant and susceptible were noted. Discussion on how the community responded during extreme climate events and famines in the past provided additional insight on the resources that contribute to their resilience. The third group explored the actions being taken in the community to adapt to climate change, focusing on the role of crop diversity in these approaches. Key results of the household survey were shared with each of the small groups using simple graphic presentations, and discussion was then opened to validate and deepen the interpretation of the results. The focus groups were led by a consistent team of field technicians with several years' experience in crop diversity projects who were knowledgeable about the folk and scientific taxonomy of local varieties. These experts verified the data to check for synonyms of varieties being used across the communities.

\subsection{Resilience self-assessment in Cachilaya}

To broaden understanding of the role of crop diversity for adaptation in the context of various environmental, social, and economic factors affecting farmers' resilience, we

Table 3 Number and gender of participants in the focus group discussions and the resilience self-assessment workshop in the different study communities on the northern Altiplano of Bolivia: $C M$ Coromata Media, $C A$ Cachilaya, $C Q$ Corqueamaya, $S U$ Suriquina, ER Erbenkalla, $R O$ Rosapata, $A N$ Antaquira, and $P U$ Pucamaya

\begin{tabular}{llll}
\hline Activity & Community & Participants (\#) & Female (\%) \\
\hline Focus group discussions & CM & 13 & 46 \\
& CA & 17 & 59 \\
& CQ & 17 & 53 \\
& SU & 17 & 65 \\
& ER & 8 & 38 \\
& RO & 7 & 71 \\
& AN & 14 & 50 \\
Resilience self- & PU & 16 & 25 \\
assessment workshop & CA & 7 & 29 \\
\hline
\end{tabular}


conducted a social-ecological resilience self-assessment in the community of Cachilaya. The assessment followed the framework of Mijatović et al. (2013) that was elaborated by Bergamini et al. (2014). It was conducted in only one of the study communities due to limited resources. The resilience self-assessment workshop was attended by seven farmers of mixed gender and age in February 2015 (Table 3). It started with participatory landscape mapping and elaboration of a climate change timeline for the last 30 years. This was followed by scoring and discussion of 20 indicators of social-ecological resilience, which comprise community assets, institutions, and practices in the domains of (1) landscape diversity and ecosystem protection, (2) biodiversity (wild and agricultural), (3) knowledge and innovation, (4) governance and social equity, and (5) livelihoods and wellbeing (Bergamini et al. 2014). The indicators were scored on a five-point scale, first by individual participants and then by the group as a whole through consensus, with higher scores indicating stronger elements of resilience (Online Resource 1). Participants were encouraged to give explanations for the scores and to discuss the processes of change occurring with respect to each indicator, thus capturing the community's perceptions and experiences regarding the factors they see contribute to or reduce their resilience.

\subsection{Data analysis}

The percentage of all respondents in the household survey $(N=193)$ that had perceived specific changes in the climate was calculated. To evaluate perceptions on crop responses to climate change, we considered the responses of those who had perceived climate change $(N=177)$ and who were growing each specific crop. We partitioned the data for growers that perceived climate change into the percentage that considered the crop as (1) resistant, (2) susceptible or (3) both resistant and susceptible to emerging stresses (depending on the variety), as well as (4) those who made no observation on the crops' response to climate change. For the summary of adaptation actions, we similarly focused only on those who had perceived climate change, calculating the percentage of those respondents who took specific actions.

Multifactor analysis (MFA) and hierarchical clustering were performed on the household survey data to assess links between farmers' adaptation actions, their perceptions of crop responses to climate change, and their crop portfolios. The analysis was performed for households that had perceived climate change. The data analysed were a mixture of quantitative and qualitative variables (Online Resource 2), which MFA is capable of handling by applying principle component analysis (PCA) for quantitative variables and multiple correspondence analysis (MCA) for categorical variables (Choisis et al. 2012). We grouped the variables into six themes: (1) climate change perceptions, (2) crop species cultivated, (3) crop and variety richness, (4) crops perceived as susceptible to climate change stresses, (5) crops perceived as tolerant to climate change stresses, and (6) adaptation actions. The themes were balanced in the global analysis of the MFA, which weighs them by the inverse of the first eigenvalue of the separate analysis tables (Lê et al. 2008). Additional variables were included in the analysis as supplementary information that did not contribute to the formation of the MFA axes or the clustering but which were correlated to the results. These supplementary variables were grouped under five themes: (1) constraints faced in adaptation, (2) community, (3) farm characteristics, (4) livestock, and (5) respondent characteristics. Following a similar approach to that applied by Choisis et al. (2012) to analyse farming system diversity, we performed hierarchical clustering on the first nine axes of the component scores of the MFA (which captured $50 \%$ of the variance) 
using Ward's criterion. The analysis was performed using the FactoMineR package (Lê et al. 2008) in the $\mathrm{R}$ environment ( $\mathrm{R}$ version 3.03; $\mathrm{R}$ Development Core Team 2008).

\section{Results}

\subsection{Perceptions of climate change}

Ninety-two per cent of respondents in the household survey perceived a change in the weather over the last 20 years. Seventy-four per cent observed an increase in temperature, and $71 \%$ observed a change in precipitation patterns - often a late onset of rains (38\%). Twenty per cent indicated that the weather has become more unpredictable, referring to rain but also hail and frost events. Increasing pest and disease pressure and soil degradation were considered to be linked to the weather changes by 56 and $22 \%$ of respondents, respectively. The observations of climate change were similar across the communities (Fig. 2).

In the focus groups, farmers expressed they have never experienced heat like in recent years. Rainfall has become more irregular, as well as frost and hail. Before, hail would typically come in the dry season (August-September), but lately it has been coming with the rains (December-March), causing damage to their crops. Frost used to come mainly in the winter period (May-June) when the communities rely on it for production of freeze dried potatoes-chuño and tunta. More recently, frosts come at any time of year and cause

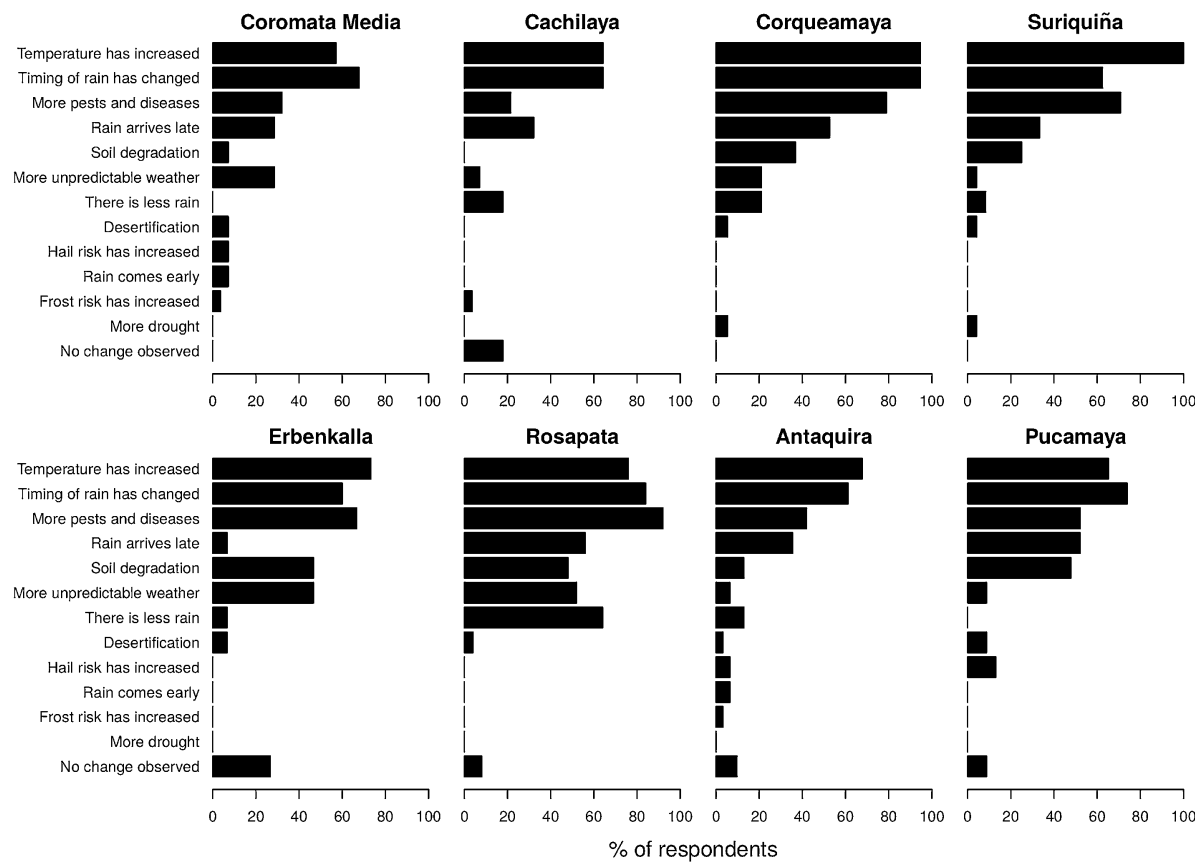

Fig. 2 Climate change perceptions of farmers in the eight study communities on the northern Bolivian Altiplano as documented in the household survey $(N=193)$. Respondents were asked to describe the weather changes they had perceived in the last 20 years and what the impacts have been in their environment. Their answers were matched to a list of common responses 
crop damage, yet they are not consistent or strong enough for the production of chuño and tunta. In some communities, rivers and wells have been drying up due to insufficient rains and high evaporation.

Pests, diseases, and soil degradation were prominent issues raised in the focus groups, which the farmers saw to be linked to climate change as well as other factors. The population sizes of pests have increased, and new species of pests and diseases have appeared. In Antaquira, Andean potato weevil (Premnotrypes latithorax) has started attacking luki (S. juzepzukii) and yari (S. ajanhuiri) potatoes, which were not previously affected by this major pest. In Erbenkalla, chiar laqu (Epicauta pennsylvanica) has appeared as a pest of cañahua, while a new pest that eats potato tubers-alicate (Forficula auricularia)—has emerged in Suriquiña. Farmers in Coromata Media noticed a new disease that rots potato tubers, which they call corcho usu (Fusarium solani). In several communities, hares (Lepus europaeus) have appeared in recent years and cause damage to quinoa, cañahua, barley, and forages. Farmers across the sites described their soils being "tired", no longer producing well, and not holding vegetation cover. In Erbenkalla, soils have become salinized. Intensive cultivation, reduced fallow periods, use of chemical inputs and tractors, in combination with insufficient rain, were seen as the causes of soil degradation. Shorter fallow periods were also seen as a factor contributing to pest problems, along with the increasing temperatures.

\subsection{Perceptions of crops' tolerance to climate change related stresses}

Forty-eight per cent of respondents in the household survey reported suffering yield declines as an impact of climate change. Minor tubers (oca, papalisa, and isaño), fava bean (Vicia faba), and pea (Pisum sativum) were reported by many growers to be susceptible to emerging climate stresses (Fig. 3). In the focus groups in Coromata Media, Cachilaya, Pucamaya, and Antaquira, minor tubers were accordingly ranked among the most susceptible crops, which often fail or have low production because of their sensitivity to frost, hail, drought, and pests (Table 4). Long growing cycles contribute to their susceptibility by increasing their exposure to these stresses. Isaño was remarked to produce well in rainy years in Pucamaya, whereas excess humidity was mentioned as a constraint for papalisa. Sensitivity to soil conditions was noted for oca in Antaquira. The focus group in Corqueamaya confirmed the vulnerability of fava bean and pea to drought and water shortage.

Perceptions on the performance of potato, quinoa, cañahua, and barley under climate change were mixed in the household survey (Fig. 3). The focus groups revealed more detailed observations on the tolerance of specific varieties to different stresses (Table 4). The potatoes most likely to fail under climate stress were varieties of $S$. tuberosum (Andigenum, Phureja, and Stenotomum groups), while the more stress-tolerant potatoes were varieties of $S$. juzepzukii, S. curtilobum, and $S$. ajanhuiri. The popular commercial potato variety huaycha (S. tuberosum Andigenum group) was considered among the most susceptible cultivations in Cachilaya and Antaquira - vulnerable to drought, frost, hail, and pests-but in Coromata Media this variety was considered to be reliable because of its frost tolerance. Luki stood out as one of the most hardy potato varieties, noted for frost tolerance in all eight communities and tolerance to drought, hail, and pests in several communities. Other potato varieties mentioned for their tolerance in more than one community were kaisalla (S. juzepzukii), choquepitu (S. curtilobum), ajanhuiri (S. ajanhuiri), and sisu (S. ajanhuiri). Across the communities, twelve potato varieties were noted to be frost tolerant, six drought tolerant, six hail tolerant, and two resistant to Andean potato weevil (Table 4). 


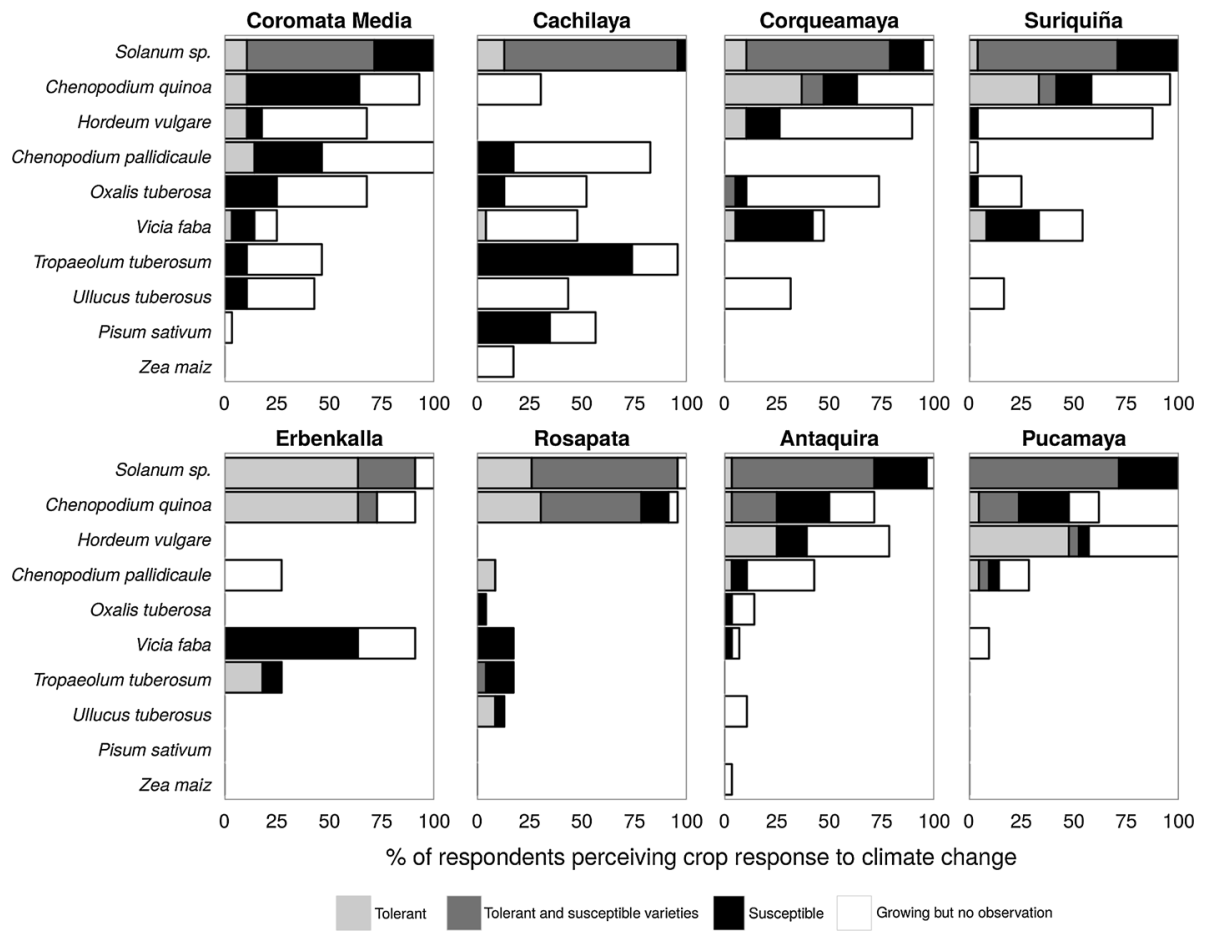

Fig. 3 Farmers' perceptions of crop tolerance to climate change stresses in eight communities on the northern Bolivian Altiplano as documented in the household survey $(N=177)$. Respondents who perceived climate change were asked which of their crops they perceived to be tolerant and susceptible to the associated stresses. Some crops were said to be both tolerant and susceptible by the same respondent due to differences between varieties

Quinoa and cañahua were ranked among the most stress-tolerant crops in the focus groups in three and five communities, respectively (Table 4). Many Andean grain varieties were appreciated for drought and frost tolerance, whereas few were recognized for tolerance to insect pests or hail. Wild quinoa (ajara; Chenopodium quinoa subsp. milleanum) and wild cañahua (lama/illamanco; Chenopodium sp.) were remarked to be tolerant to all the major climate stresses for crop production (frost, hail, drought and pests) and were recognized as alternatives to cultivated grains in periods of climate stress in five communities (Table 4). Farmers remarked that these wild grains, which grow spontaneously in their fields and along the river, would never disappear because of their tolerance to drought and frost. Several communities recalled using wild quinoa and cañahua as famine food during past drought events in which they experienced severe crop failures and death of livestock. Wild apharus potatoes ( $S$. acaule), which grow in field margins, llaytha algae (Nostoc commune) from the river, and the achacana cactus (Cereus sp.) in the hills were other important famine foods.

\subsection{Adaptation actions}

Seventy-three per cent of respondents who perceived climate change in the household survey reported taking action to adapt. Different households used different approaches within each community (Fig. 4). Overall, the most common adaptation action was seeking 


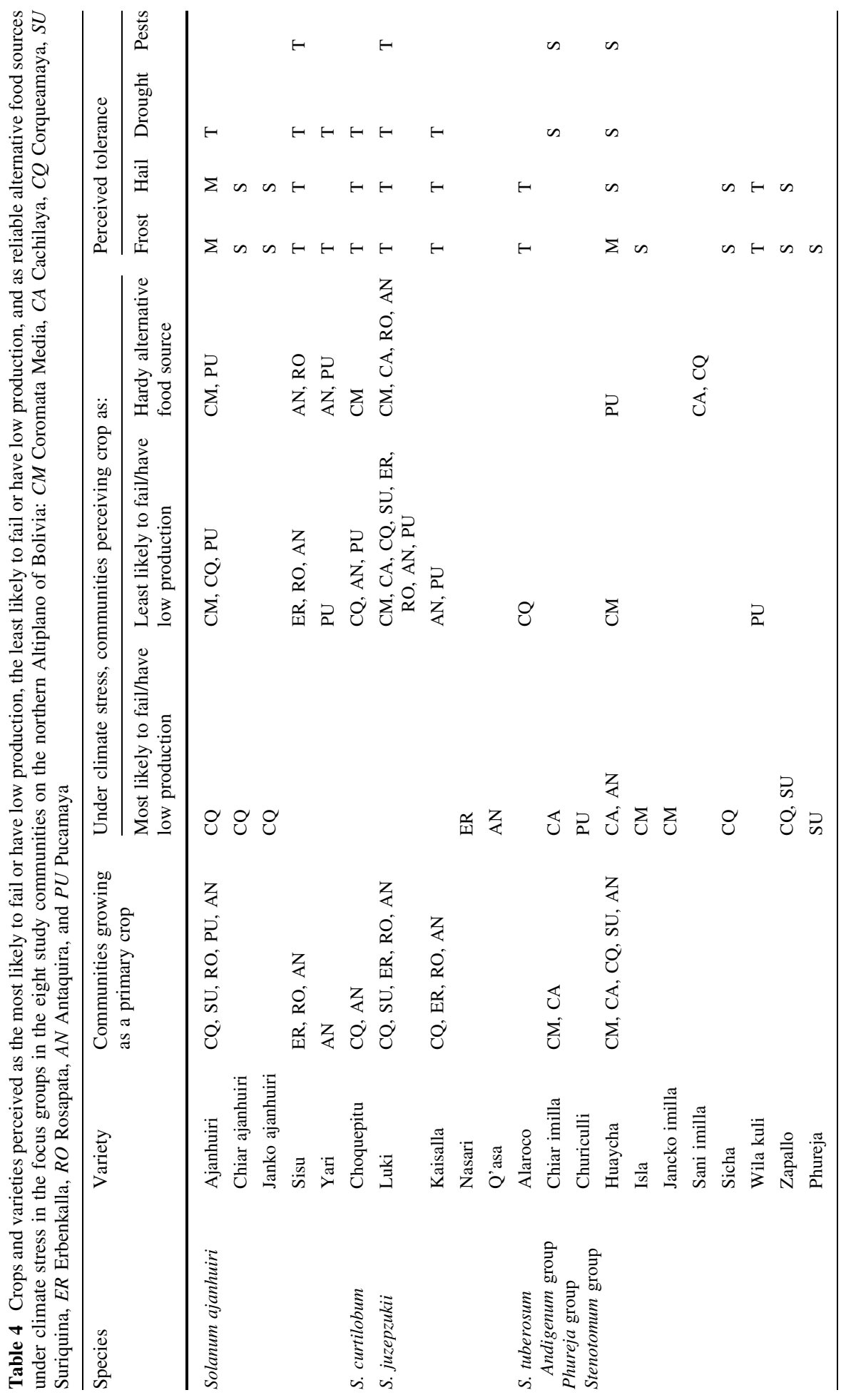




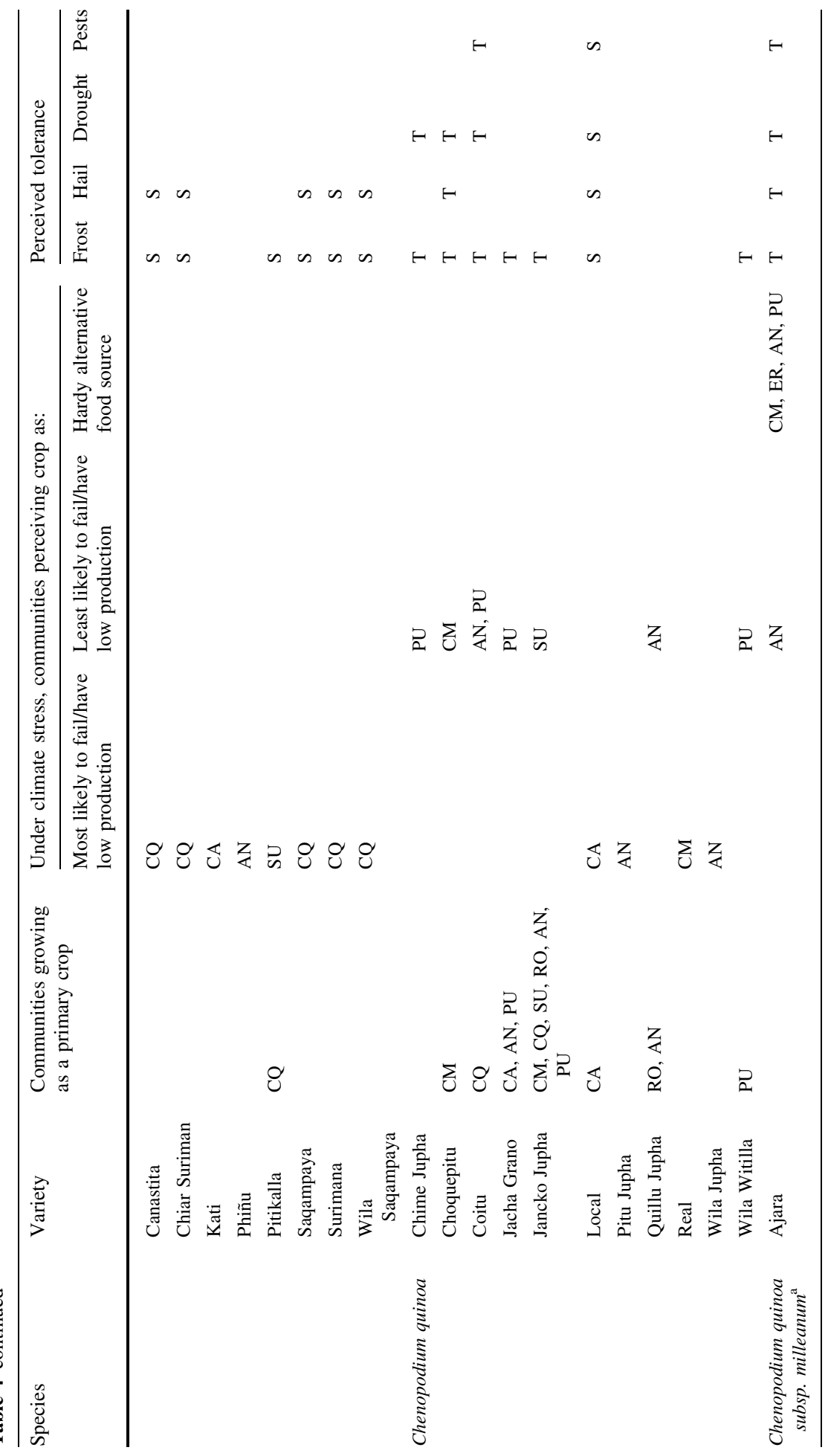




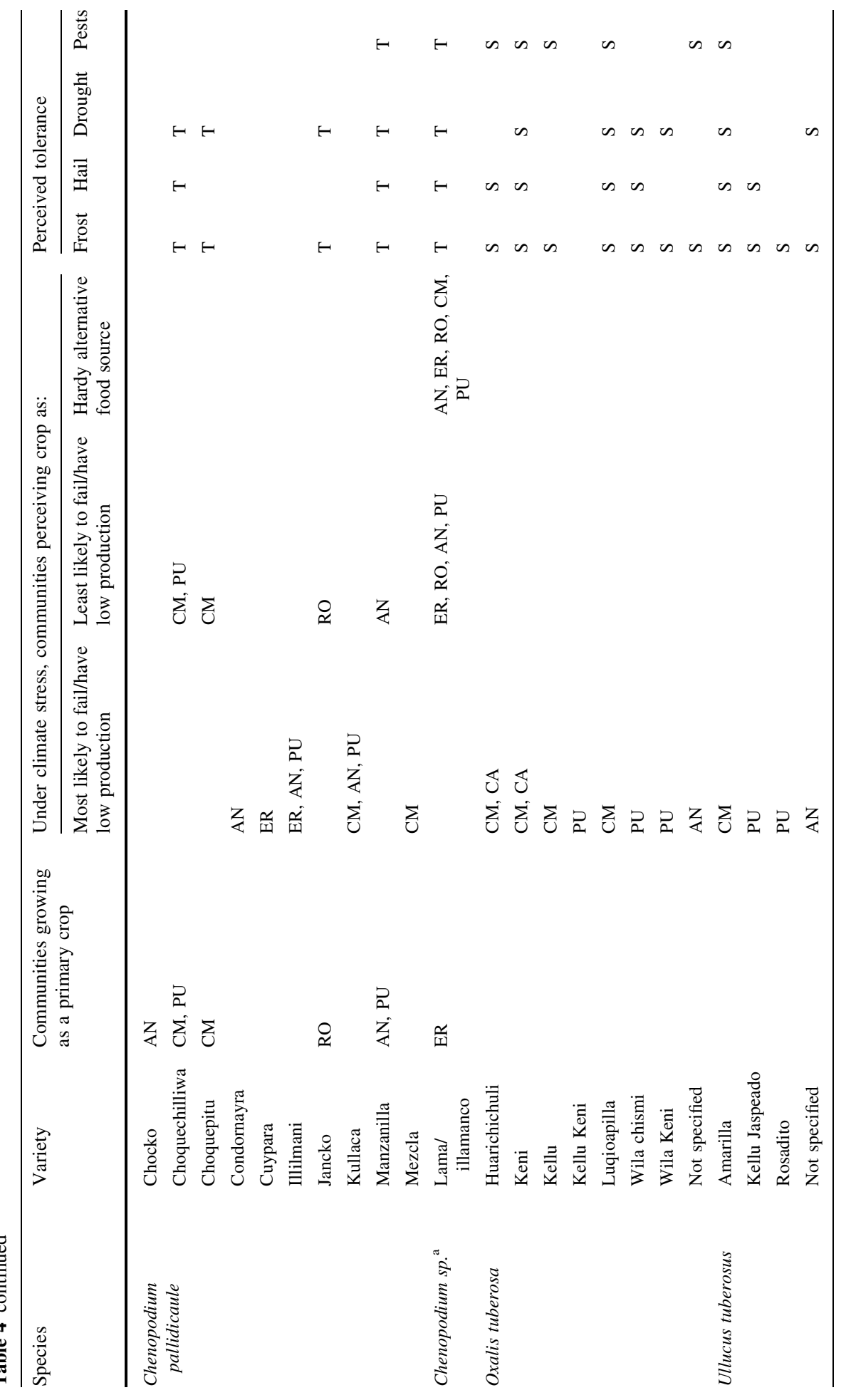




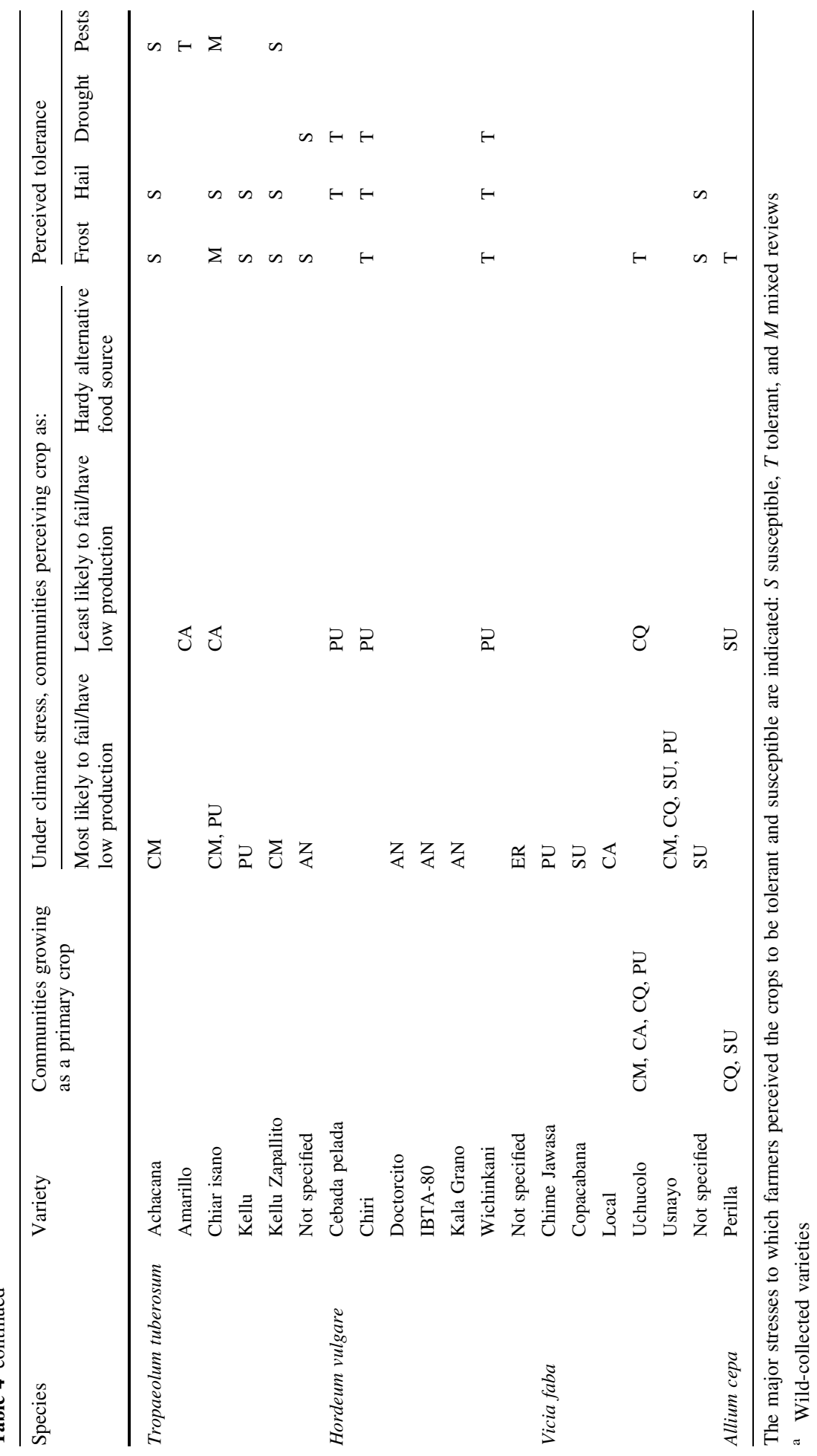




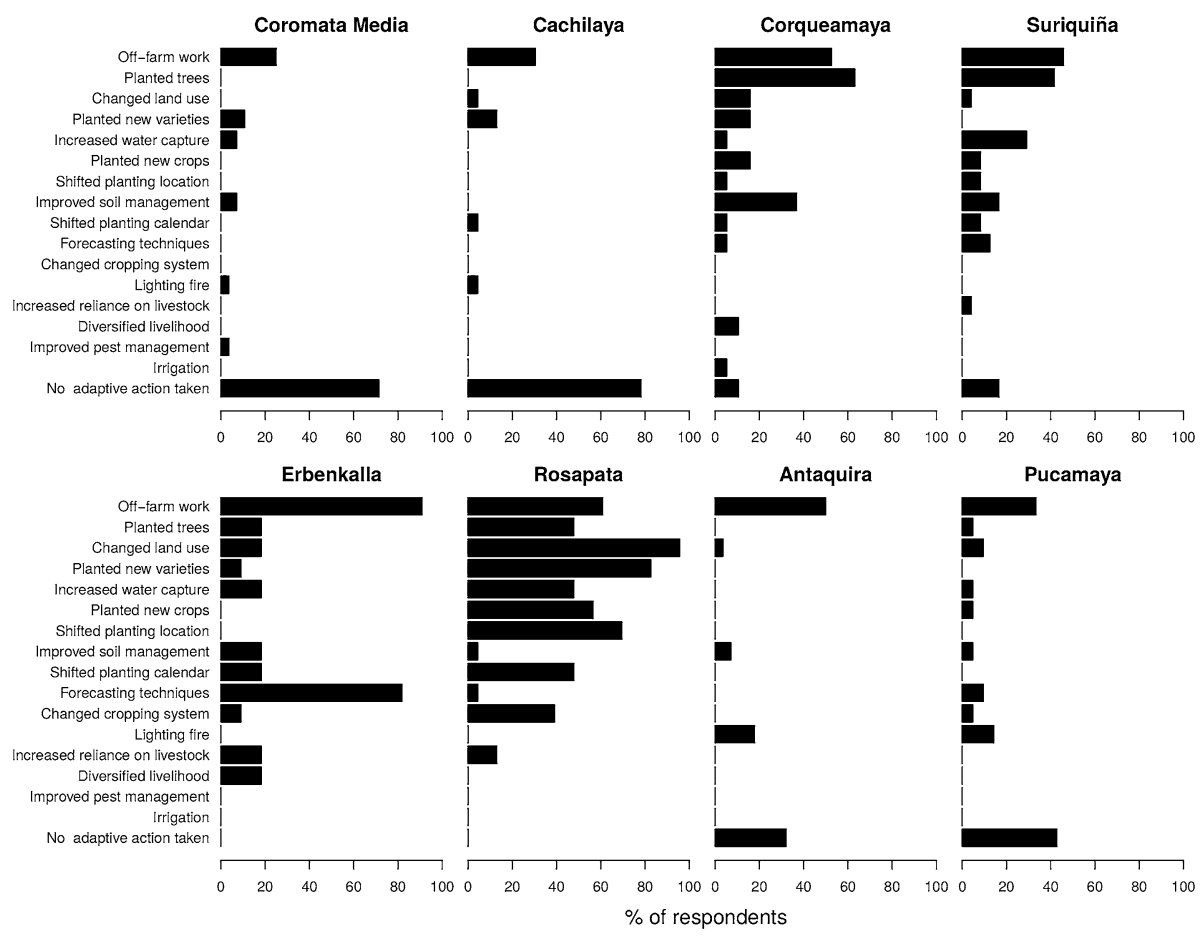

Fig. 4 Climate change adaptation actions of farmers surveyed in eight communities on the northern Bolivian Altiplano as documented in the household survey $(N=177)$. Respondents who perceived climate change were asked what actions they had taken to adapt to the effects. Their responses were matched to a list of common responses

off-farm work (45\%), which may be seen as a coping strategy. Twenty per cent of households had planted trees. A similar number (19\%) planted new crops or varieties, often disease-resistant $(14 \%)$ or early-maturing varieties $(6 \%)$. Other adaptation actions were changing land use (18\%), rainwater harvesting (14\%), improving soil management (11\%), shifting planting locations (11\%), changing cropping schedules (10\%), using forecasting techniques (9\%), and increasing reliance on livestock (3\%). In Antaquira and Pucamaya, several farmers reported poking plots with fire $(6 \%)$, which is a traditional practice to ward off frost or hail by dissipating the clouds with smoke.

The focus group discussions revealed additional detail on farmers' adaptation actions and the role of crop diversity in these approaches. In all communities, farmers were using seed exchanges to access new varieties tolerant to frost, hail, and other stresses. Rural fairs and markets were important sources of new varieties, and NGOs had also provided some new seeds. In previous decades, all the communities had introduced sweet and floury varieties of $S$. tuberosum (Andigenum group) that are preferred for their taste and marketability - most notably the huaycha variety but also others such as chiar imilla, jancko imilla, sani imilla, and wila imilla. The introduced potato varieties that to some extent replaced local varieties can produce larger and more abundant tubers, but their performance varies from year to year. The large size of huaycha tubers, in combination with warmer weather, was also observed to challenge chuño and tunta production. Increasing commercial production was not limited to potatoes. In 2011, farmers in Coromata Media 
replaced cañahua with quinoa, motivated by its high market price. In Suriquiña, a yellow grain quinoa variety (quinoa amarilla) was replaced with the main commercial variety Quinoa Real. Taking advantage of the warming weather, farmers in Suriquiña and Corqueamaya introduced onion (Allium cepa) and other vegetables as cash crops. Onion was considered a very hardy crop, but was remarked for its susceptibility to hail. A shift towards keeping more dairy cattle for commercial production of milk and cheese was reported in Cachilaya, which displaced some potato, quinoa, and barley to grow more alfalfa (Medicago sativa) as forage. Commercial dairy production was also introduced in the previous decade in Coromata Media, Erbenkalla, and Antaquira, which was associated with a shift from local breeds to the cara negra breed.

In all communities, farmers were using manure to improve soil fertility. In Rosapata, farmers had cleared vegetation to establish plots in previously uncultivated areas, which were more fertile and free of pests. All the focus groups recognized that longer fallow periods would be necessary to recover soil fertility and control pests and diseases, but that land shortage limits their chances of implementing this strategy. Spreading ashes on crop leaves was a practice used in most communities for pest control. The communities were also applying new techniques for controlling Andean potato weevil that they learned from NGO trainings, including the use of organic pesticides and selection of healthy seeds.

\subsection{Links between adaptation actions, crop portfolios, and perceptions of crop responses to climate change}

The MFA and clustering analysis revealed three groups of households with similar climate change perceptions and adaptation actions relative to their crop portfolios (Fig. 5a). The correlation circle for the quantitative variables is shown in Fig. 5b, and the modalities of the qualitative variables are shown in Fig. 5c. Households were separated along the first axis of the MFA (representing 12\% of the inertia) mainly by their level of crop diversity and whether they had taken action to adapt to climate change (Online Resource 3). The second axis (representing 7\% of the inertia) distinguished households that cultivated barley, perceived this crop to be tolerant to climate change, and had not changed crop varieties as an adaptive action. The cluster analysis reflected the correlations in the MFA and showed similar perception and use of crop diversity under climate change within communities. The resulting three clusters are described below and summarized in detail in Online Resource 4.

One cluster was composed primarily of households from Cachilaya who maintained high levels of crop species and variety diversity. Cañahua, minor tubers, peas, and maize were grown by many and often seen as susceptible to emerging conditions under climate change. Nonetheless, the majority of households in this cluster (80\%) did not take action to adapt to climate change. A second cluster was distinguished along the first axis of the MFA with households largely from Rosapata and Erbenkalla that had lower crop species and variety diversity and that had taken various actions to adapt to climate change, including shifting planting schedules and locations, using different crops and varieties, and increasing rainwater capture. These households more commonly observed unpredictable weather, warmer temperatures, declining rainfall, increased pest and disease pressure, and soil degradation. Fava bean was observed by many as being susceptible to these stresses. By contrast, quinoa and isaño were considered tolerant to the emerging conditions. A third cluster was distinguished from the other two along the second axis of the MFA. This group was composed mainly of households from Pucamaya, Antaquira, and Suriquiña. These households had a relatively lower level of variety diversity. The majority 

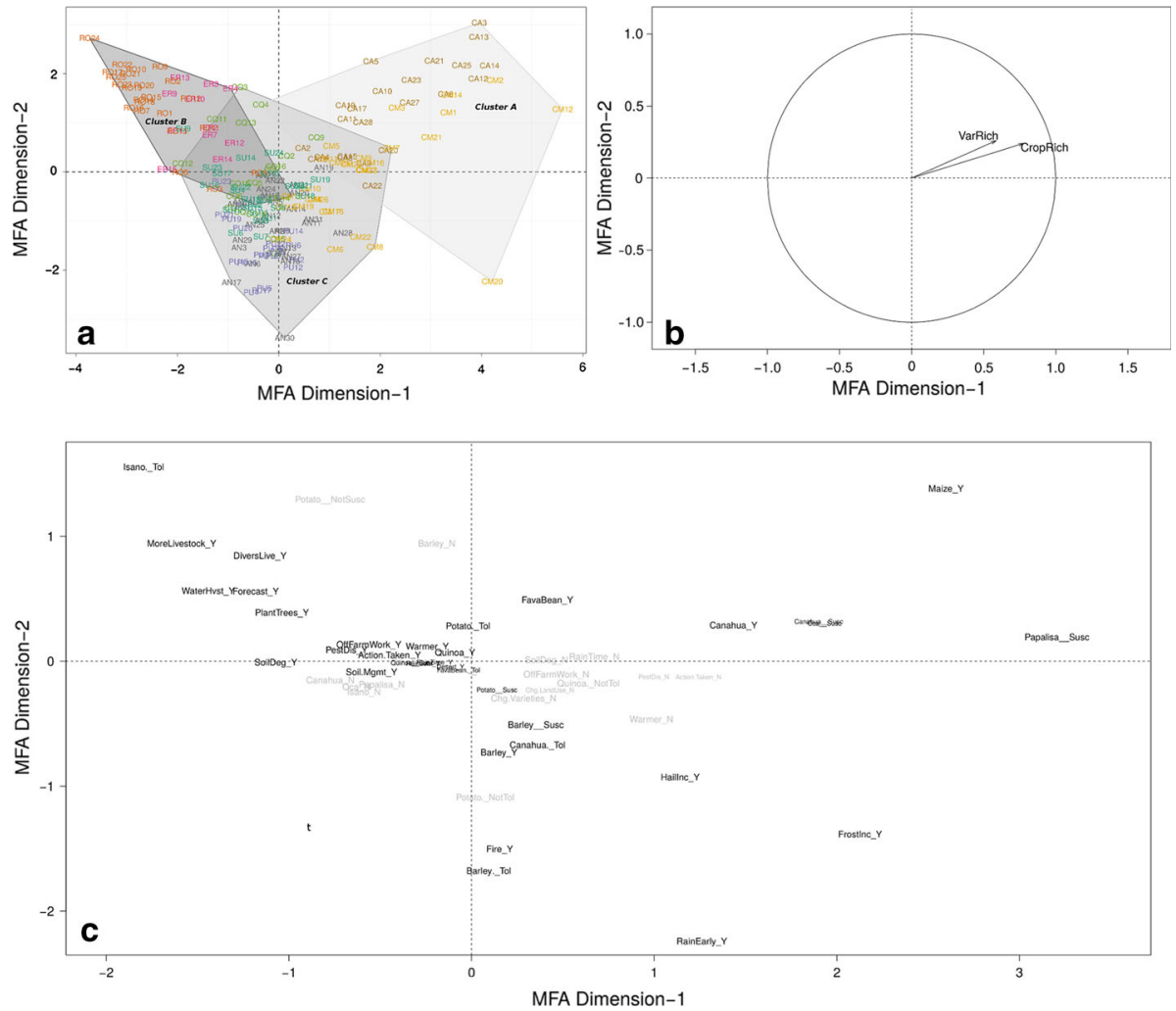

Fig. 5 Results of the MFA and cluster analysis on the household survey data $(N=177)$, examining correlations between farmers' climate change perceptions and adaptation actions relative to their crop portfolios. The projection on the first two MFA dimensions is shown for a households bound by their clusters, $\mathbf{b}$ the correlation circle of quantitative variables, and $\mathbf{c}$ factor levels of qualitative variables that had an above-average contribution to the first and second dimensions. For binary qualitative variables, the positive level $($ Yes $=\mathrm{Y}$, susceptible $=$ Susc or tolerant $=$ Tol) is shown in black and the negative level $(\mathrm{No}=\mathrm{N}$, not Susceptible $=$ NotSusc, not tolerant $=$ NotTol $)$ in grey. Negative levels of binary variables with coordinates less than 0.3 on the first or second dimension were omitted for readability. Details on the abbreviations and levels of the factors are shown in Online Resource 2

cultivated barley and many considered this crop to be tolerant to climate change stresses. Potatoes, by contrast, were seen by most in the cluster as susceptible to emerging climate conditions. The traditional practice of lighting fire to ward off frost and hail was linked to this cluster.

\subsection{Participatory social-ecological resilience assessment in Cachilaya}

The results of the participatory social-ecological resilience assessment conducted in Cachilaya are presented in Table 5, which shows the consensus scores and trends for 20 indicators of social-ecological resilience and how multiple factors affect the use of crop diversity in coping with, adapting to, and recovering from climate change related stresses. The indicator on recovery and regeneration-processes that are central to resilience-was given a medium score. Farmers explained that recovery from shocks is challenging because 


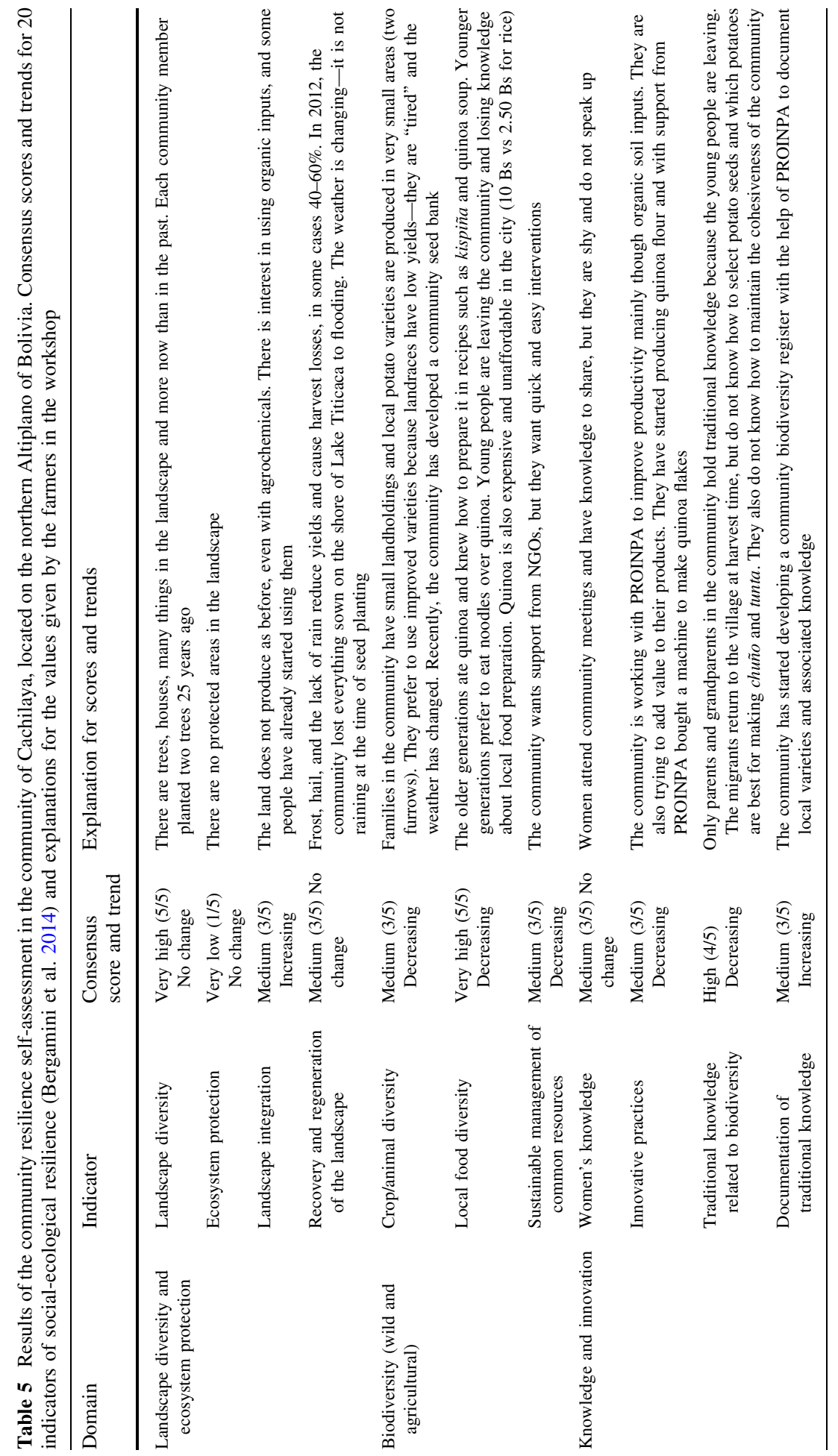




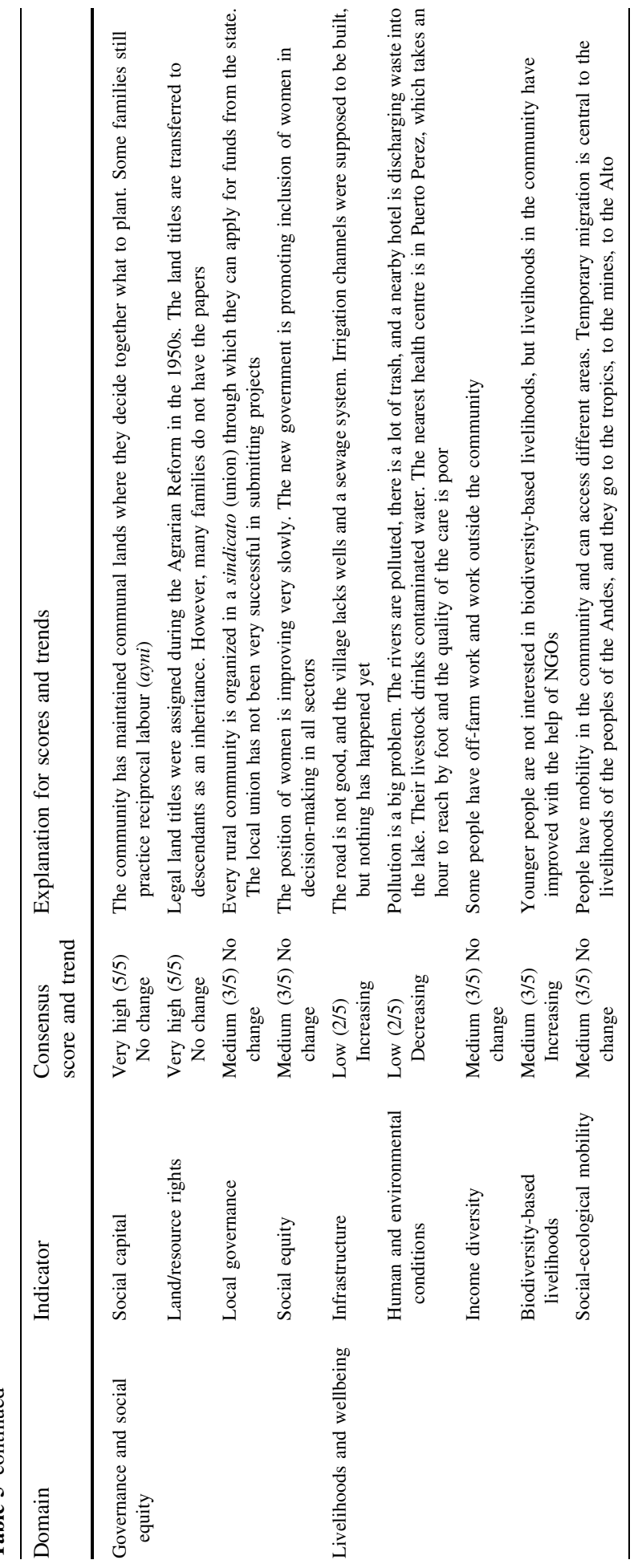


manifold stresses (floods, droughts, frost, and hail) occur in close succession within and between years (Online Resource 5a). Social capital and resource rights were among the strongest elements of resilience in the community. The traditional land-use system, which has been maintained over time, comprises a mosaic of distinct land-use types, including communally managed lands (aynoqas) and wetlands (kjochi iranas), as well as private family plots (sayañas) (Online Resource 5b). Decisions about crop cultivation on communal lands are made collectively based on an evaluation of the previous harvest and other social and environmental factors. However, there is concern that such communal institutions may disintegrate in the future as young people leave the village. The outmigration of young people is contributing to an erosion of traditional knowledge on practices for seed selection and cleaning, crop rotation, and traditional food recipes. The diversity of local foods was perceived to be high but declining, along with diversity in the landscape, crops, and animals. Local varieties of potato are cultivated in small plots, while commercial varieties are cultivated in large areas. Shrinking land resources, decreasing soil productivity, lack of ecosystem protection, and declining human and environmental health (e.g. pollution of rivers and Lake Titicaca) have a negative effect on resilience.

\section{Discussion}

Farmers' perceptions of climate change in the eight study communities are in line with empirical data and other studies on farmers' perceptions in the Andean highlands (Perez et al. 2010; Thibeault et al. 2010; Valdivia et al. 2010; McDowell and Hess 2012; Seiler et al. 2013; Lennox 2015). The increasing problem of pests and diseases experienced by farmers is associated with rising temperatures and further exacerbated by shifts towards monoculture, pest-susceptible varieties, and abbreviated crop rotation schedules (Parsa 2010; Perez et al. 2010; McDowell and Hess 2012; Poveda et al. 2012). Adaptation actions reported in our study communities (e.g. adjusting planting dates, changing crop composition, and improving soil and water management) are similar to those adopted by farmers in others parts of the Andean highlands and the world (e.g. Young and Lipton 2006; Bryan et al. 2009; Deressa et al. 2011; Habiba et al. 2012; Boillat and Berkes 2013; Mijatović et al. 2013; Le Dang et al. 2014).

Farmers' perceptions of crop responses to stresses linked to climate change are likewise in alignment with other studies. Modelling investigations have predicted that $S$. tuberosum will be more negatively affected by climate change than $S$. juzepczukii and $S$. ajanhuiri (Sanabria and L'Homme 2013; Condori et al. 2014). The latter species are known for their frost and drought tolerance and are also recognized for resistance to insect pests and late blight (Phytophthora infestans) (Martinez et al. 2001; Browman 2003; Baldinelli 2014; Condori et al. 2014). The frost tolerance of S. juzepczukii, S. curtilobum, and S. ajanhuiri can be traced to their wild progenitors: $S$. acaule and S. bolivense (Rodríguez et al. 2010; Ovchinnikova et al. 2011; Machida-Hirano 2015). Gene flow between wild and cultivated types is an important element of crop adaptation in their centres of origin (e.g. Rodríguez et al. 2010; Hufford et al. 2013; Mutegi et al. 2015), and the role of crop wild relatives as a source of stress tolerance and resistance traits for crop breeding is well acknowledged (Hajjar and Hodgkin 2007; Jansky et al. 2013). This study also revealed the value of hardy wild relatives of quinoa, cañahua, and potato as famine foods for Altiplano communities in periods of climate stress. The high glycoalkaloid content of $S$. juzepczukii and $S$. curtilobum inherited from their wild progenitors confers resistance to pests and diseases 
(Tingey 1984; Machida-Hirano 2015). Nonetheless, in this study, farmers observed that due to rising temperatures, $S$. juzepczukii is starting to be affected by pests. These potatoes also are becoming more difficult to freeze-dry, which is a critical practice to reduce their toxin content before consumption and ensure potato supply in lean periods (de Haan et al. 2010; Perez et al. 2010; Machida-Hirano 2015).

No previous studies to our knowledge have indicated a vulnerability of oca, isaño, and papalisa to climate change, although their agronomic traits offer some explanations for the farmers' observations. The long cycle of these crops (7-8 months) exposes them to frost, hail, and drought events (Hernandez-Bermejo and Leon 1992). Oca is intolerant to high temperatures (Emshwiller et al. 2009), and papalisa is vulnerable to viral disease (Hernandez-Bermejo and Leon 1992), which may be aggravated by rising temperatures. Minor tubers and fava bean - which was also observed to be vulnerable to climate change-are integral in traditional crop rotation systems that maintain soil productivity, help control pests and disease, and provide dietary diversity (Orlove and Godoy 1986; Bianco and Sachs 1998; Grau et al. 2003). Minor tubers typically follow potato in the second year of traditional rotations, while isaño is intercropped with other tubers to leverage its anti-pest and anti-nematode properties (Orlove and Godoy 1986; Hernandez-Bermejo and Leon 1992; Bianco and Sachs 1998; Grau et al. 2003). The vulnerability of these crops to climate change stresses could disrupt their roles in the agroecosystem.

The crops used in farmers' adaptation actions were not necessarily those perceived to be more tolerant to climate change stresses. Introduction of "sweet" potato varieties $(S$. tuberosum Andigenum group) and commercial vegetables was partly encouraged by warmer temperatures, but these cultivations were observed to be vulnerable to hail and drought, which are becoming more frequent. Commercial quinoa varieties were also introduced in several communities, displacing local varieties and cañahua-a related Andean grain that is more tolerant of frost and drought than quinoa (Gade 1970). These changes in crops and varieties reflect farmers' responses to the changing climate, as well as shifting social and economic conditions. The adoption and expansion of commercial crops and varieties contribute to a diversified livelihood portfolio (Zimmerer 2013), but can lead to maladaptation as observed by McDowell and Hess (2012) in another municipality in the Department of La Paz: In Palca, shifts from hillside subsistence farming to commercial vegetable production in irrigated fields increased farmers' sensitivity to climate change by raising dependence on unreliable water sources and hail-sensitive crops, as well as exposing them to market volatility (McDowell and Hess 2012).

While the introduction of commercial crops was reported as an adaptation action, traditional diversity-based risk management was not perceived as adaptation. The MFA and cluster analysis revealed that households with higher levels of crop and variety diversity, especially in Cachilaya, did not report taking action to adapt to the changing climate. Yet field observations confirm that farmers in this community continue to use traditional risk management strategies, such as planting some of their plots to a mixture of local potato varieties (chalis). Maintaining crop and variety portfolios with different traits and tolerances provides response diversity that mitigates losses from weather and market shocks (di Falco and Perrings 2003; Halloy et al. 2005; di Falco and Chavas 2009; Perez et al. 2010; Hakala et al. 2012; McDowell and Hess 2012; Kahiluoto et al. 2014). Most households in all the communities cultivated several potato varieties, including non-bitter and hardy bitter varieties. However, this practice was not reported as an adaptation action in the survey, likely because it was not novel and so was not perceived as "adaptation". Additional or improved methods of enquiry may better capture diversity-based practices that farmers consciously and unconsciously use to mitigate risk and support crop 
adaptation, for instance capturing more detail on variety traits, their spatial and temporal arrangement in the landscape, farmers' seed selection and exchange practices, and the use of wild or weedy relatives (Brush et al. 1981; Johns and Keen 1986; Thomas et al. 2015).

The results of the resilience assessment in Cachilaya showed that crop diversity and associated knowledge are negatively affected by a range of interacting factors including climate change, soil degradation, and outmigration of young people. Off-farm migration, partly driven by land scarcity (Tapia 2006), results in a disruption of intergenerational interactions and the transmission of traditional knowledge associated with crop diversity (e.g. practices for seed selection and processing bitter potatoes). Local ecological knowledge obtained through long-term experiences and observations provides a basis for innovation and adaptation (Balbo et al. 2016), so its loss can have a negative effect on resilience. On the other hand, incorporation of scientific findings into "traditional" knowledge is important for building adaptive capacity (Berkes et al. 2000; Berkes and Turner 2006; Valdivia et al. 2013; Reyes-García et al. 2014), especially as climate change is bringing new challenges at a rapid rate. Approaches that blend traditional and scientific knowledge can also help address environmental degradation (Altieri et al. 2012), which according to the results of the resilience assessment is a serious problem-especially the pollution of local rivers and Lake Titicaca, which is causing declining fish stocks (Monroy et al. 2014) and is a hazard for livestock and human health. Further degradation of the local resource base will reduce the resilience of Altiplano communities (McDowell and Hess 2012). Cachilaya's community cohesion and self-organization, reflected in local institutions, make an important part of their adaptive capacity (Rodima-Taylor 2012; Berkes and Ross 2013; Balbo et al. 2016) and can provide a platform for devising sustainable climate adaptation actions.

\section{Conclusions}

Climate change is bringing ever greater uncertainty and exposure to multiple climate stresses on the northern Altiplano of Bolivia. Drought, frost, hail, and pest and disease outbreaks are becoming increasingly frequent and unpredictable within and between years. Few crops and varieties were perceived as tolerant to all these major stresses, which explains why farmers continue to maintain several varieties at the household level with different tolerance traits. This risk management strategy has persisted in all the study communities despite the commercialization and intensification of local cropping systems. However, it was not perceived as adaptation, while introduction of commercial crops was perceived as adaptation.

Households across the study communities introduced and expanded the area under commercial "sweet" potatoes, and in some communities, households started more commercial-oriented production of quinoa, vegetables, and dairy. The shift to commercial production reflects farmers' responses and adaptation to warmer temperatures as well as new economic opportunities. While this approach contributes to a diversified livelihood portfolio, the greater sensitivity of commercial crops and varieties to climate stresses, as compared to some traditional cultivations (e.g. bitter potatoes), may lead to maladaptation. The displacement of local crops and varieties reduces response diversity in farmers' crop portfolios and therefore their capacity to adapt to climate shocks and long-term change.

While our results show key roles for stress-tolerant local crops and varieties in securing harvests under climate change, our results also revealed that some local crops and varieties 
are threatened by emerging climate conditions-notably the minor tubers oca, papalisa, and isaño. Furthermore, while varieties of bitter potato stood out for being highly stress tolerant, the traditional freeze-drying that enables their consumption and provides a longterm food store is challenged by warming temperatures. The use of these crops could diminish with the progression of climate change, along with their roles in crop rotations and risk management strategies, unless hardier varieties are found or developed for the vulnerable crops or innovative techniques are developed for processing bitter potatoes.

Strengthening farmers' resilience to climate change on the northern Altiplano of Bolivia will require a combination of actions including maintaining and expanding crop and variety portfolios and restoring soil and ecosystem health. Because of the multiple stresses, solutions that focus on only one trait (e.g. drought tolerance) will be inadequate and maintaining crop portfolios with a range of responses to climate stress will remain an important element of resilience. One of the main challenges will be to take opportunities for diversification and commercial crop production without losing response diversity and valuable adaptive traits found in local varieties. Maintaining the presence of wild relatives of potato, quinoa, and cañahua in the landscape will ensure a source of traits for crop adaptation and food in periods of extreme climate stress. Reversing the loss of traditional knowledge and complementing it with scientific knowledge will be important to support development of local solutions to face the multiple challenges for resilience.

Acknowledgements The authors are grateful for the farmers' time and participation in the household surveys and focus groups in the eight study communities. Our sincere thanks to Ronnie Mamani, Alex Duran, and Marisol Luque for their assistance in facilitating the focus groups and for contributing their knowledge and support to the study. This research was conducted in the context of the project "Reinforcing the resilience of poor rural communities in the face of food insecurity, poverty and climate change through on-farm conservation of local agrobiodiversity" supported by the International Fund for Agricultural Development and the CGIAR Research Programme on Climate Change Agriculture and Food Security. The participatory resilience self-assessment was part of the project "Supporting agrobiodiversity maintenance and use in the context of land management decisions" funded by the Christensen Fund. Many thanks to Toby Hodgkin, Didier Bazile, Gea Galluzzi, and six anonymous reviewers for their comments on earlier drafts of this manuscript, which greatly improved the study. Further regards to Gaia Gullotta for help with preparing the map of our study sites.

\section{Compliance with ethical standards}

Conflict of interest The authors declare that they have no conflict of interest.

Open Access This article is distributed under the terms of the Creative Commons Attribution 4.0 International License (http://creativecommons.org/licenses/by/4.0/), which permits unrestricted use, distribution, and reproduction in any medium, provided you give appropriate credit to the original author(s) and the source, provide a link to the Creative Commons license, and indicate if changes were made.

\section{References}

Altieri, M. A., Funes-Monzote, F. R., \& Petersen, P. (2012). Agroecologically efficient agricultural systems for smallholder farmers: Contributions to food sovereignty. Agronomy for Sustainable Development, 32(1), 1-13.

Balbo, A. L., Gómez-Baggethun, E., Salpeteur, M., Puy, A., Biagetti, S., \& Scheffran, J. (2016). Resilience of small-scale societies: A view from drylands. Ecology and Society, 21(2), 53.

Baldinelli, G. M. (2014). Agrobiodiversity conservation as a coping strategy: Adapting to climate change in the northern highlands of Bolivia. Consilience. The Journal of Sustainable Development, 11(1), $153-166$. 
Bazile, D., Fuentes, F., \& Mujica, Á. (2013). Historical perspectives and domestication. In A. Bhargava \& S. Srivastava (Eds.), Quinoa: Botany, production and uses (pp. 16-35). Wallingford, UK: CABI.

Bergamini, N., Dunbar, W., Eyzaguirre, P., Ichikawa, K., Matsumoto, I., Mijatovic, D., et al. (2014). Toolkit for the indicators of resilience in socio-ecological production landscapes and seascapes (SEPLS). United Nations University Institute for the Advanced Study of Sustainability: Tokyo, Bioversity International: Rome, Institute for Global Environmental Strategies: Japan, and the United Nations Development Programme: New York.

Berkes, F., \& Ross, H. (2013). Community resilience: Toward an integrated approach. Society and Natural Resources, 26(1), 5-20.

Berkes, F., \& Turner, N. J. (2006). Knowledge, learning and the evolution of conservation practice for social-ecological system resilience. Human Ecology, 34(4), 479-494.

Berkes, F., Colding, J., \& Folke, C. (2000). Rediscovery of traditional ecological knowledge as adaptive management. Ecological Applications, 10(5), 1251-1262.

Bianco, M., \& Sachs, C. (1998). Growing oca, ulluco, and mashua in the Andes: Socioeconomic differences in cropping practices. Agriculture and Human Values, 15, 267-280.

Boillat, S., \& Berkes, F. (2013). Perception and interpretation of climate change among Quechua farmers of Bolivia: Indigenous knowledge as a resource for adaptive capacity. Ecology and Society, 18(4), 21.

Bradley, R. S., Vuille, M., Diaz, H. F., \& Vergara, W. (2006). Threats to water supplies in the tropical Andes. Science, 312(5781), 1755-1756.

Browman, D. L. (2003). Nature across cultures. In H. Selin (Ed.), Nature across cultures: Views of nature and the environment in non-western cultures. Netherlands: Springer.

Brush, S. B., Carney, H. J., \& Humán, Z. (1981). Dynamics of Andean potato agriculture. Economic Botany, 35(1), 70-88.

Brush, S. B., Taylor, J. E., \& Bellon, M. R. (1992). Technology adoption and biological diversity in Andean potato agriculture. Journal of Development Economics, 39(2), 365-387.

Bryan, E., Deressa, T. T., Gbetibouo, G. A., \& Ringler, C. (2009). Adaptation to climate change in Ethiopia and South Africa: Options and constraints. Environmental Science \& Policy, 12(4), 1-24.

Choisis, J. P., Thévenet, C., \& Gibon, A. (2012). Analyzing farming systems diversity: A case study in south-western France. Spanish Journal of Agricultural Research, 10(3), 605-618.

Condori, B., Hijmans, R. J., Ledent, J. F., \& Quiroz, R. (2014). Managing potato biodiversity to cope with frost risk in the high Andes: A modeling perspective. PLoS ONE, 9(1), 1-11.

De Haan, S. (2009). Potato diversity at height: Multiple dimensions of farmer-driven in situ conservation in the Andes. Ph.D. thesis, Wageningen University, The Netherlands.

De Haan, S., Burgos, G., Arcos, J., Ccanto, R., Scurrah, M., Salas, E., et al. (2010). Traditional processing of black and white chuño in the Peruvian Andes: Regional variants and effect on the mineral content of native potato cultivars. Economic Botany, 64(3), 217-234.

Del Castillo, C., Mahy, G., \& Winkel, T. (2008). La quinoa en Bolivie: Une culture ancestrale devenue culture de rente"bio-equitable". Biotechnology, Agronomy and Society and Environment, 12(4), 445-454.

Deressa, T. T., Hassan, R. M., \& Ringler, C. (2011). Perception of and adaptation to climate change by farmers in the Nile basin of Ethiopia. The Journal of Agricultural Science, 149(1), 23-31.

Di Falco, S., \& Chavas, J. P. (2009). On crop biodiversity, risk exposure, and food security in the highlands of Ethiopia. American Journal of Agricultural Economics, 91(3), 599-611.

Di Falco, S., \& Perrings, C. (2003). Crop genetic diversity, productivity and stability of agroecosystems: A theoretical and empirical investigation. Scottish Journal of Political Economy, 50(2), 207-216.

Emshwiller, E., Theim, T., Grau, A., Nina, V., \& Terrazas, F. (2009). Origins of domestication and polyploidy in oca (Oxalis tuberosa; Oxalidaceae). 3. AFLP data of oca and four wild, tuber-bearing taxa. American Journal of Botany, 96(10), 1-10.

Folke, C., Carpenter, S. R., Walker, B., Scheffer, M., Chapin, T., \& Rockström, J. (2010). Resilience thinking: Integrating resilience, adaptability and transformability. Ecology and Society, 15(4), 20.

Gade, D. W. (1970). Ethnobotany of cañihua (Chenopodium pallidicaule), rustic seed crop of the Altiplano. Economic Botany, 24(1), 55-61.

Garcia, M., Raes, D., Jacobsen, S. E., \& Michel, T. (2007). Agroclimatic constraints for rainfed agriculture in the Bolivian Altiplano. Journal of Arid Environments, 71(1), 109-121.

Geerts, S., Raes, D., Garcia, M., Del Castillo, C., \& Buytaert, W. (2006). Agro-climatic suitability mapping for crop production in the Bolivian Altiplano: A case study for quinoa. Agricultural and Forest Meteorology, 139(3-4), 399-412.

Gilles, J. L., Thomas, J. L., Valdivia, C., \& Yucra, E. S. (2013). Laggards or leaders: Conservers of traditional agricultural knowledge in Bolivia. Rural Sociology., 78(1), 51-74. 
Grau, A., Ortega Dueñas, R., Nieto Cabrera, C., \& Hermann, M. (2003). Mashua (Tropaeolum tuberosum Ruíz \& Pav.). Promoting the conservation and use of underutilized and neglected crops, 25. International Potato Center: Lima and International Plant Genetic Resources Institute: Rome.

Habiba, U., Shaw, R., \& Takeuchi, Y. (2012). Farmer's perception and adaptation practices to cope with drought: Perspectives from northwestern Bangladesh. International Journal of Disaster Risk Reduction, 1(1), 72-84.

Hajjar, R., \& Hodgkin, T. (2007). The use of wild relatives in crop improvement: A survey of developments over the last 20 years. Euphytica, 156(1), 1-13.

Hakala, K., Jauhiainen, L., Himanen, S. J., Rötter, R., Salo, T., \& Kahiluoto, H. (2012). Sensitivity of barley varieties to weather in Finland. The Journal of Agricultural Science, 150(2), 145-160.

Halloy, S. R. P., Ortega, R., Yager, K., \& Seimon, A. (2005). Traditional Andean cultivation systems and implications for sustainable land use. Acta Horticulturae, 670, 31-55.

Hellin, J., \& Higman, S. (2005). Crop diversity and livelihood security in the Andes. Development in Practice, 15(2), 165-174.

Hernández Bermejo, J. E., \& León, J. (1992). Cultivos marginados: Otra perspectiva de 1492. Rome: FAO.

Hufford, M. B., Lubinksy, P., Pyhäjärvi, T., Devengenzo, M. T., Ellstrand, N. C., \& Ross-Ibarra, J. (2013). The genomic signature of crop-wild introgression in maize. PLoS Genetics, 9(5), e1003477.

IPCC. (2014). Climate change 2014: Impacts, adaptation, and vulnerability; Summaries, frequently asked questions, and cross-chapter boxes. In C. B. Field, V. R. Barros, D. J. Dokken, K. J. Mach, M. D. Mastrandrea, T. E. Bilir, et al. (Eds.), Fifth assessment report of the intergovernmental panel on climate change. World Meteorological Organization: Geneva, Switzerland.

Jackson, L., van Noordwijk, M., Bengtsson, J., Foster, W., Lipper, L., Pulleman, M., et al. (2010). Biodiversity and agricultural sustainability: From assessment to adaptive management. Current Opinion in Environmental Sustainability, 2(1-2), 80-87.

Jansky, S. H., Dempewolf, H., Camadro, E. L., Simon, R., Zimnoch-Guzowska, E., Bisognin, D. A., et al. (2013). A case for crop wild relative preservation and use in potato. Crop Science, 53, 46-754.

Johns, T., \& Keen, S. L. (1986). Ongoing evolution of the potato on the Altiplano of western Bolivia. Economic Botany, 40(4), 409-424.

Kahiluoto, H., Kaseva, J., Hakala, K., Himanen, S. J., Jauhiainen, L., Rutter, R. P., et al. (2014). Cultivating resilience by empirically revealing response diversity. Global Environmental Change, 25(1), 186-193.

La Barre, W. (1947). Potato taxonomy among the Aymara Indians of Bolivia. Acta Americana, 5, 83-103.

Le Dang, H., Li, E., Bruwer, J., \& Nuberg, I. (2014). Farmers' perceptions of climate variability and barriers to adaptation: Lessons learned from an exploratory study in Vietnam. Mitigation and Adaptation Strategies for Global Change, 19(5), 531-548.

Lê, S., Josse, J., \& Husson, F. (2008). FactoMineR: An R package for multivariate analysis. Journal of Statistical Software, 25(1), 1-18.

Lennox, E. (2015). Double exposure to climate change and globalization in a Peruvian highland community. Society and Natural Resources, 28(7), 781-796.

Machida-Hirano, R. (2015). Diversity of potato genetic resources. Breeding Science, 65(1), 26-40.

Malice, M., \& Baudoin, J.-P. (2009). Genetic diversity and germplasm conservation of three minor Andean tuber crop species. Biotechnologie, Agronomie, Société et Environnement, 13(3), 441-448.

Martinez, C. A., Loureiro, M. E., Oliva, M. A., \& Maestri, M. (2001). Differential responses of superoxide dismutase in freezing resistant Solanum curtilobum and freezing sensitive Solanum tuberosum subjected to oxidative and water stress. Plant Stress, 160(3), 505-515.

McDowell, J. Z., \& Hess, J. J. (2012). Accessing adaptation: Multiple stressors on livelihoods in the Bolivian highlands under a changing climate. Global Environmental Change, 22(2), 342-352.

Mijatović, D., Van Oudenhoven, F., Eyzaguirre, P., \& Hodgkin, T. (2013). The role of agricultural biodiversity in strengthening resilience to climate change: Towards an analytical framework. International Journal of Agricultural Sustainability, 11(2), 95-107.

Monroy, M., Maceda-Veiga, A., \& de Sostoa, A. (2014). Metal concentration in water, sediment and four fish species from Lake Titicaca reveals a large-scale environmental concern. Science of the Total Environment, 487(15), 233-244.

Mutegi, E., Snow, A. A., Rajkumar, M., Pasquet, R., Ponniah, H., Daunay, M.-C., et al. (2015). Genetic diversity and population structure of wild/weedy eggplant (Solanum insanum, Solanaceae) in southern India: Implications for conservation. American Journal of Botany, 102(1), 140-148.

Orlove, B. S., \& Godoy, R. (1986). Sectoral fallowing systems in the Central Andes. Journal of Ethnobiology, 6(1), 169-204.

Ovchinnikova, A., Krylova, E., Gavrilenko, T., Smekalova, T., Zhuk, M., Knapp, S., et al. (2011). Taxonomy of cultivated potatoes (Solanum section Petota: Solanaceae). Botanical Journal of the Linnean Society, 165(2), 107-155. 
Parsa, S. (2010). Native herbivore becomes key pest after dismantlement of a traditional farming system. American Entomologist, 56(4), 242-251.

Perez, C., Nicklin, C., Dangles, O., Vanek, S., Sherwood, S., Halloy, S., et al. (2010). Climate change in the high Andes: Implications and adaptation strategies for small-scale farmers. The International Journal of Environmental, Cultural, Economic and Social Sustainability, 6(5), 71-88.

Poveda, K., Martínez, E., Kersch-Becker, M. F., Bonilla, M. A., \& Tscharntke, T. (2012). Landscape simplification and altitude affect biodiversity, herbivory and Andean potato yield. Journal of Applied Ecology, 49(2), 513-522.

Pusadee, T., Jamjod, S., Chiang, Y.-C., Rerkasem, B., \& Schaal, B. A. (2009). Genetic structure and isolation by distance in a landrace of Thai rice. Proceedings of the National Academy of Sciences of the United States of America, 106(33), 13880-13885.

Reyes-García, V., Aceituno-Mata, L., Calvet-Mir, L., Garnatje, T., Gómez-Baggethun, E., Lastra, J. J., et al. (2014). Resilience of traditional knowledge systems: The case of agricultural knowledge in home gardens of the Iberian Peninsula. Global Environmental Change, 24, 223-231.

Rodima-Taylor, D. (2012). Social innovation and climate adaptation: Local collective action in diversifying Tanzania. Applied Geography, 33, 128-134.

Rodríguez, F., Ghislain, M., Clausen, A. M., Jansky, S. H., \& Spooner, D. M. (2010). Hybrid origins of cultivated potatoes. Theoretical and Applied Genetics, 121(6), 1187-1198.

Ruiz, K. B., Biondi, S., Oses, R., Acuña-Rodríguez, I. S., Antognoni, F., Martinez-Mosqueira, E. A., et al. (2014). Quinoa biodiversity and sustainability for food security under climate change: A review. Agronomy for Sustainable Development, 34(2), 349-359.

Sanabria, J., \& L'Homme, J. P. (2013). Climate change and potato cropping in the Peruvian Altiplano. Theoretical and Applied Climatology, 112(3-4), 683-695.

Seiler, C., Hutjes, R. W. A., \& Kabat, P. (2013). Likely ranges of climate change in Bolivia. Journal of Applied Meteorology and Climatology, 52(6), 1303-1317.

Tapia, N. (2006). Agroecologia y agricultura campesina sostenible en los Andes bolivianos: El Caso del ayllu Majasaya Mujlli, departamento de Cochabamba, Bolivia (2nd ed.). AGRUCO: La Paz, Bolivia.

Thibeault, J., Seth, A., Garcia, M., Mayor, U., Andrés, D. S., \& Paz, L. (2010). Changing climate in the Bolivian Altiplano: CMIP3 projections for extremes of temperature and precipitation. Journal of Geophysical Research Atmospheres, 115(c), 2070.

Thiele, G. (1999). Informal potato seed systems in the Andes: Why are they important and what should we do with them? World Development, 27(1), 83-99.

Thomas, M., Thépot, S., Galic, N., Jouanne-Pin, S., Remoué, C., \& Goldringer, I. (2015). Diversifying mechanisms in the on-farm evolution of crop mixtures. Molecular Ecology, 24(12), 2937-2954.

Tingey, W. M. (1984). Glycoalkaloids as pest resistance factors. American Potato Journal, 61(3), 157-167.

Valdivia, C., Seth, A., Gilles, J. L., García, M., Jiménez, E., Cusicanqui, J., et al. (2010). Adapting to climate change in Andean ecosystems: Landscapes, capitals, and perceptions shaping rural livelihood strategies and linking knowledge systems. Annals of the Association of American Geographers, 100(4), 818-834.

Valdivia, C., Thibeault, J., Gilles, J. L., Garcia, M., \& Seth, A. (2013). Climate trends and projections for the Andean Altiplano and strategies for adaptation. Advances in Geosciences, 33, 69-77.

Vargas, A., Elzinga, D. B., Rojas-Beltran, J. A., Bonifacio, A., Geary, B., Stevens, M. R., et al. (2011). Development and use of microsatellite markers for genetic diversity analysis of cañahua (Chenopodium pallidicaule Aellen). Genetic Resources and Crop Evolution, 58(5), 727-739.

Velásquez-Milla, D., Casas, A., Torres-Guevara, J., \& Cruz-Soriano, A. (2011). Ecological and sociocultural factors influencing in situ conservation of crop diversity by traditional Andean households in Peru. Journal of Ethnobiology and Ethnomedicine, 7, 40.

Vigouroux, Y., Barnaud, A., Scarcelli, N., \& Thuillet, A. C. (2011). Biodiversity, evolution and adaptation of cultivated crops. Comptes Rendus-Biologies, 334(5-6), 450-457.

Vuille, M., Francou, B., Wagnon, P., Juen, I., Kaser, G., Mark, B. G., et al. (2008). Climate change and tropical Andean glaciers: Past, present and future. Earth-Science Reviews, 89(3-4), 79-96.

Young, K. R., \& Lipton, J. K. (2006). Adaptive governance and climate change in the tropical highlands of Western South America. Climatic Change, 78(1), 63-102.

Zimmerer, K. S. (1991). Labor shortages and crop diversity in the southern Peruvian sierra. Geographical Review, 81(4), 414-432.

Zimmerer, K. S. (2010). Biological diversity in agriculture and global change. Annual Review of Environment and Resources, 35(1), 137-166.

Zimmerer, K. S. (2013). The compatibility of agricultural intensification in a global hotspot of smallholder agrobiodiversity (Bolivia). Proceedings of the National Academy of Sciences of the United States of America, 110(8), 2769-2774. 